\title{
Narrazioni visuali attraverso il tempo e lo spazio: trame e metafore di connessioni per lo spazio pubblico
}

\author{
Alessandra Meschini \\ Alessandro Basso
}

Abstract

II contributo intende trattare alcuni aspetti relativi all'arte poliedrica dell'artista sarda Maria Lai, considerata una delle menti più dinamiche e significative nel panorama dell'arte contemporanea, attraverso l'analisi di alcune sue opere. II suo linguaggio narrativo aderisce ad una poetica di connessione tra gli elementi che lascia sempre intatto il senso polimaterico e multisignificante delle parti unite, dapprima attraverso il segno cucito e successivamente attraverso opere nello spazio esterno e azioni di arte partecipativa. Sottolineando che tutto è collegato - il presente con il passato, la conoscenza trasversale con l'immaginario collettivo - la Lai esprime una percezione del senso dell'arte che le permette di trasformare anche un oggetto quotidiano, nato per essere estetico ma funzionale, in un oggetto poetico, in un 'generatore di riflessione' capace di insegnare a sognare e a ricordare.

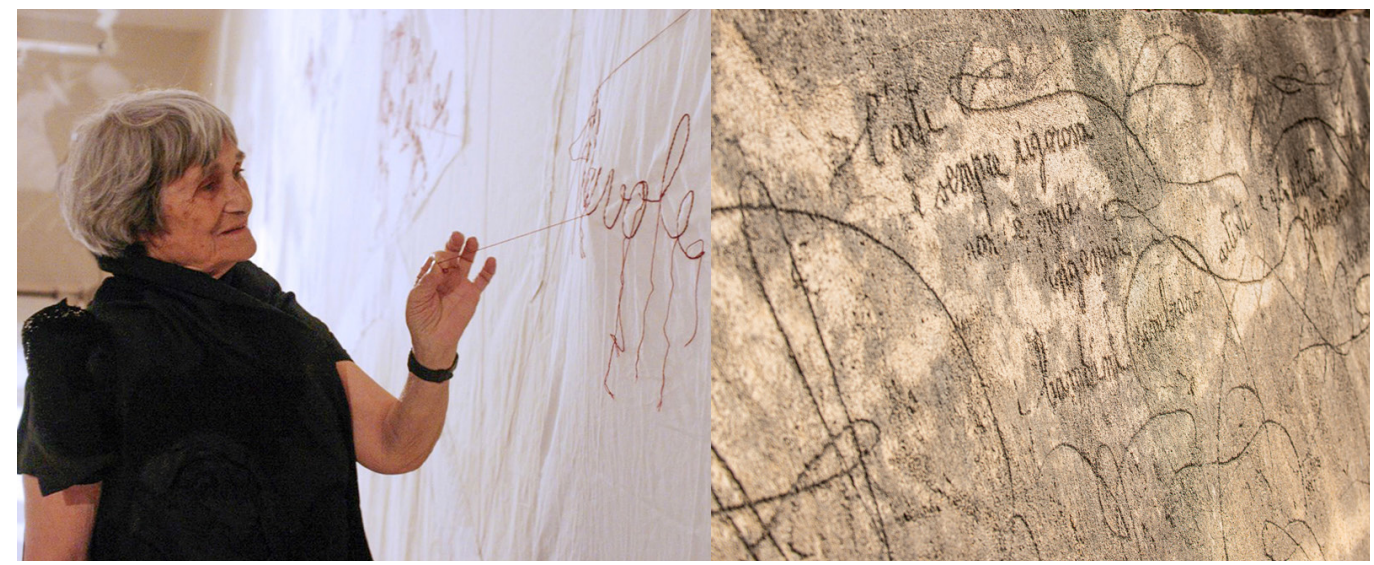




\section{Introduzione}

Legare, collegare, cucire, tessere, accostare, coinvolgere, relazionare, condividere, partecipare, ma anche trama, ordito, collage, rete, racconto; verbi coniugati 'all'infinito' e sostantivi molto 'rappresentativi' della poetica di Maria Lai, artista sarda che ha fatto del connettere a svariati livelli il senso del suo vivere, della sua ricerca e della sua opera.

Figura femminile dal respiro internazionale, tra le più interessanti della storia dell'arte del dopoguerra italiano ma riconosciuta come meritava solo dopo la sua scomparsa, ha sempre lavorato in una dimensione solitaria e riflessiva, prediligendo il silenzio al clamore.
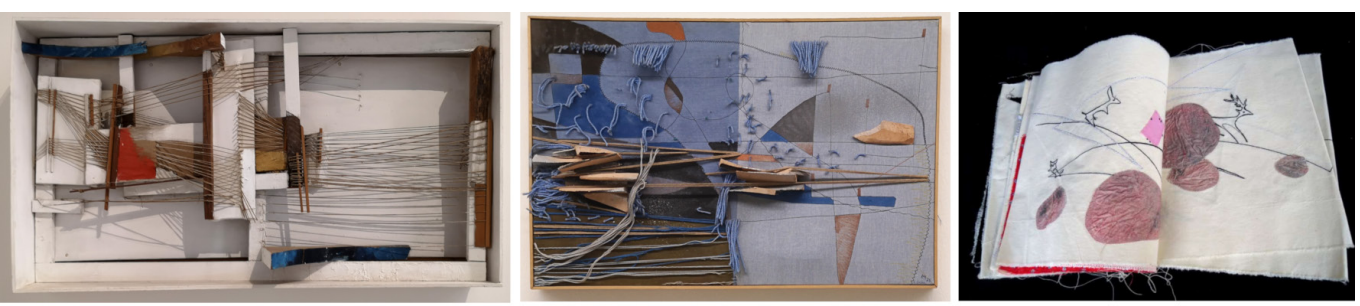

Fig. I. Telaio in sole e mare (197I); tela cucita A Luisa (1975); fiaba cucita, Le magie di Mario Pietra (1983), Geografia per Giuliana (1997) lenzuolo cucito (2007) libro cucito Le parole imprigionate (2008).
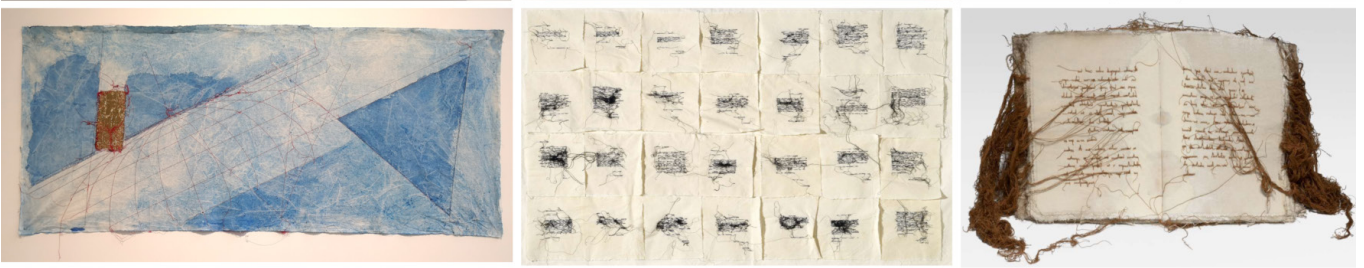

La sua arte, da molti definita concettuale ma che va oltre le classificazioni, è intrisa della sua radice isolana, fatta di memorie di manualità artigiana e di narrazioni orali millenarie apprese nell'infanzia. Infatti, se pur eccellente disegnatrice e scultrice, a partire dagli anni Sessanta ha iniziato "a guardare l'arte da tanti punti di vista diversi, tutti quelli che potevano essere proposti" [Lai 2005]. Sostituendo l'ago alla matita, lavorando con stoffe e tessuti in cui il filo diviene segno, ha creato opere - telai polimaterici, tele e fiabe cucite, libri e lenzuoli cuciti, geografie (fig. I) - che perseguono una ricerca di conciliazione di materie e forme dove il filo "che unisce luoghi e intenzioni" [Lai 1984-2004], il tessere nel doppio significato materico e concettuale, divengono metafora di connessione, di luoghi e traccie del pensiero, di memoria [Cuccu, Lai 2002 p. 19], quindi una base su cui sviluppare infinite variazioni.

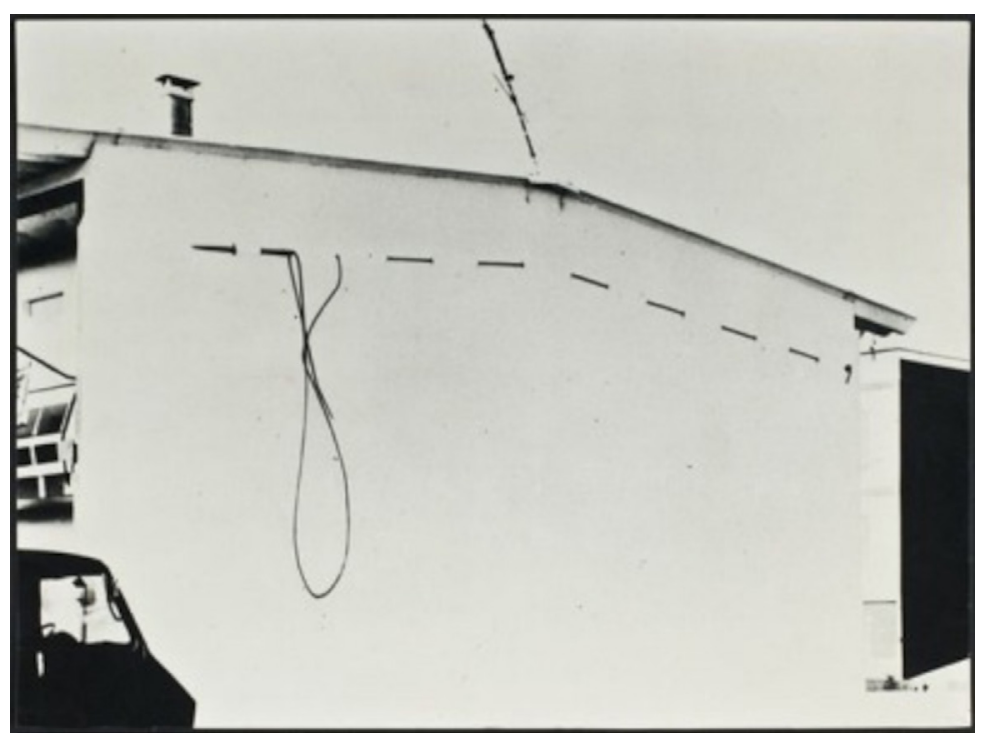


Fig. 3. La testimonianza di Legarsi alla montagna immortalata in una serie di foto in bianco e nero di Piero Berengo Gardin pol colorate dall'artista.
Negli anni Ottanta, anticipando quella che poi fu definita "estetica relazionale" [Bourriaud $2010]$ e differenziandosi dalla Land Art e dalla Pubblic Art, inizia a concepire interventi per lo spazio pubblico in forme sia di azioni di cretività condivisa, sia di arte permanente immersa nel paesaggio, sviluppando una pratica di dialogo in cui il filo diviene simbolo di una nuova comunicabilità che crea legami fra le persone, ai luoghi, alla storia [Birrozzi, Pugliese 2007, pp. 31-35; Pontiggia 2017, p. I5l].

L'avvio di tale fase è avvenuto con l'intervento ambientale Casa Cucita ( 1979) - una imbastitura sul muro esterno di un edificio a Selargius (fig. 2) - ma soprattutto con Legarsi alla montagna (198I), la sua prima opera di arte relazionale in cui, rinnovando le proprie modalità, si serve di una leggenda millenaria che narra di una bambina rimasta miracolosamente salva da una frana per inseguire un nastro azzurro (l'arte). Quest'opera assume grande importanza per la sua valenza antropologico-sociale: una trasformazione del paesaggio attraverso cui viene riconfigurata la percezione dei luoghi sancendo una riconciliazione tra una terra arida, dura e selvaggia e una comunità di uomini che sembrano smettere di amarla (fig. 3). Focalizzando l'attenzione su tale ultima produzione e trattando alcune significative e diversificate opere l'articolo intende mettere in evidenza le relazioni tra l'arte della Lai e i temi della comunicazione e narrazione visiva, ovvero il legame che in esse si stabilisce tra linguaggio creativo e pensiero a livello percettivo.
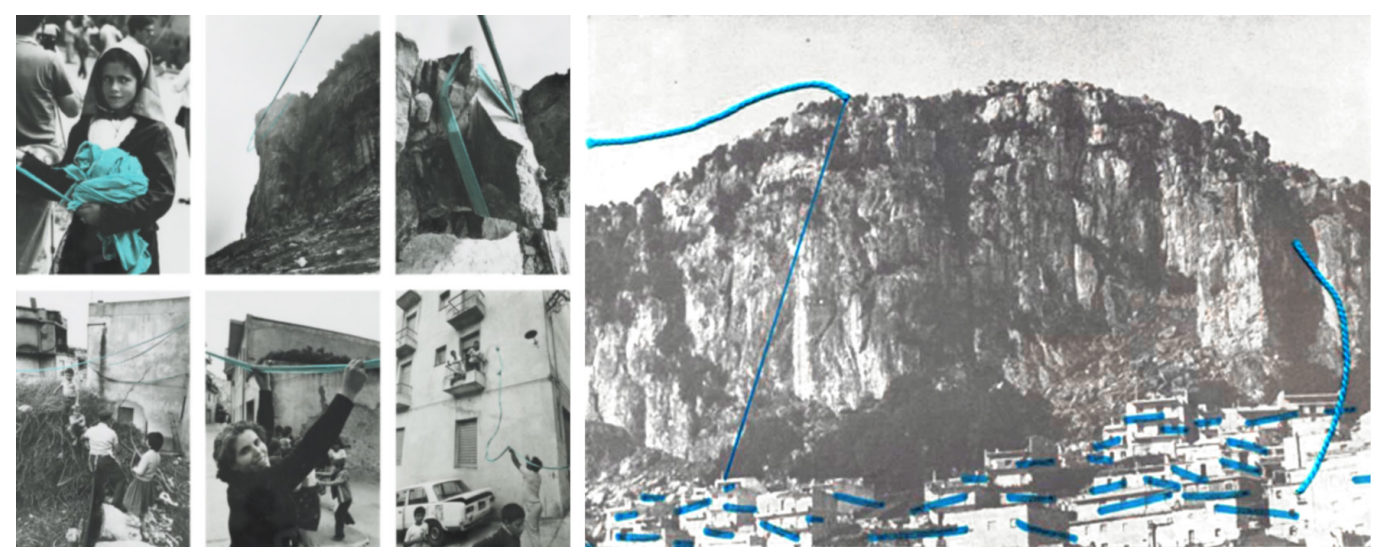

\section{Camerino e la metafora dei varani}

L'intervento La disfatta dei varani (1983), sempre citato ma in realtà poco documentato, è stato un progetto fortemente sentito da Maria Lai benché mai realizzato. Per approfondire lo studio si è riusciti ad intervistare l'allora Assessore alla Cultura di Camerino, Dott.ssa Vera Santarelli, ovvero colei che propose la Lai a Camerino, che segui l'artista nei numerosi incontri finalizzati alla realizzazione di quest'opera di azione collettiva e fu testimone degli accadimenti.

II titolo dell'opera condensa in sé sia la complicata rete di connessioni che l'artista aveva individuato, sia l'origine del rifiuto alla realizzazione della performance. Anzitutto due aspetti della storia di Camerino colpirono l'immaginario della Lai: da un lato l'immagine di una famiglia, quella dei Da Varano (signori della città per quasi 300 anni) dilaniata da una guerra fratricida (eccidio dei Varano) per lotte interne di potere [Medici 2002]; dall'altro lato la raffigurazione di un 'cane marino' a volte rappresentato anche come drago alato con corpo squamato contenuta nel cimerio di uno stemma storico di Giulio Cesare Da Varano ucciso con i suoi tre figli da Cesare Borgia nel 1502 [Paino 200 I, pp. I09- I24]. La Lai probabilmente associò questa figura mitologica a uno dei più grandi rettili viventi, il drago o varano di Komodo. Inoltre l'artista raccolse altre suggestioni dai vicoli stretti dall'impianto medievale, dal toponimo del quartiere Le Conce che le suggerì l'idea della pelle e dall'immagine topografica della città in cui il disegno in forma allungata la riportava ancora alla figura del varano [Santarelli 1984, p. 2] (fig. 4). 
Collegando tutte queste immagini la Lai creò il 'gioco' di parole del titolo spiegando: "di Camerino mi ha colpito il senso del labirinto dentro la città [...] L'architettura dominante [...] dà allo spazio urbano un senso di terribilità" [Capulli 1984, p. 2]; di una città "che ha patito per lotte, guerre, distruzioni, violenze umane e naturali ma che è sempre riuscita a risorgere" [Lai 1988, p. 23]. "Ho quindi elaborato un'immagine che contenesse insieme stupore e paura [...]. Di questa immagine è presa in considerazione la pelle", [Capulli I 984, p. 2] "trofeo simbolico di una vittoria dell'uomo contro la 'bestia', contro sé stesso, contro le avversità" [Lai 1988, p. 23].

Fig. 4. Insegne di Giulio Cesare da Varano al Palazzo Ducale di Camerino: insegna dipinta nella sala degli sposi, stemmi lapidei nel quadriportico. Dettaglio decorativo sul portale della chiesa di San Francesco a Camerino. Mappa storica e vista zenitale attuale del centro storico di Camerino.
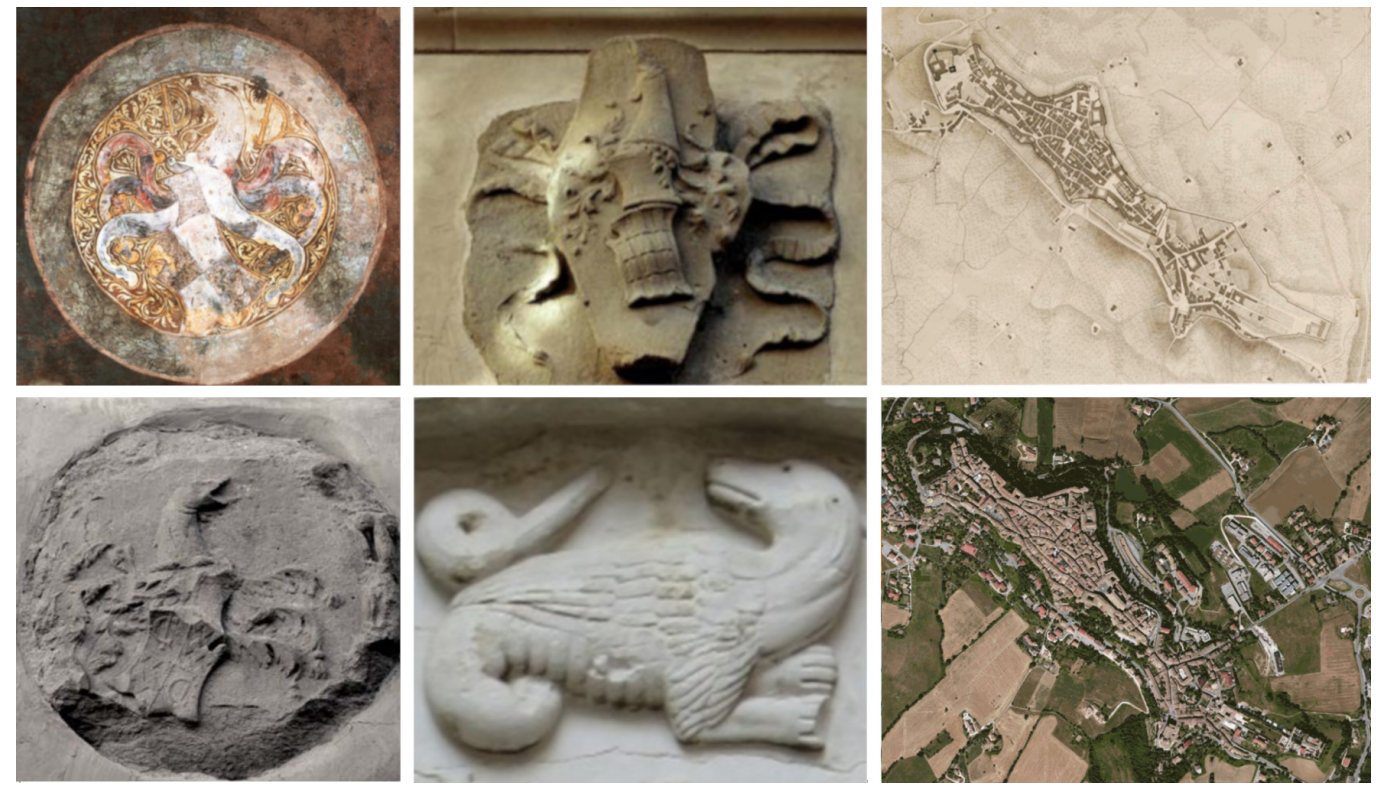

Il progetto prevedeva una operazione corale che coinvolgeva tutte le scuole e associazioni della città. Bambini e ragazzi avrebbero fabbricato dei varani di carta velina che, legati a dei palloncini bianchi, sarebbero volati tutti insieme ad un segnale dell'artista. Intanto lei, riprendendo lo strumento del cucito come metafora di dialogo tra diversità, avrebbe realizzato dei grandi varani con l'utilizzo di un patchwork di stoffe di materiale povero (fig. 5a) con l'idea di collocarli in diversi punti della città. Per documentare la performance la Lai aveva previsto, come ad Ulassai, il fotografo e operatore Rai Piero Berengo Gardin. L'intento complessivo era quello di dare l'avvio ad una promozione d'arte nel territorio con cadenza biennale.

Purtroppo la dirigenza delle scuole, le associazioni e l'amministrazione comunale non riuscirono ad entrare nella logica dell'iniziativa, al contrario videro nell'accostamento contrastante con il varano animale un'offesa alla grandiosità storica della città. Di sicuro la Lai aveva toccato degli aspetti della storia di Camerino che forse si preferiva fossero raccontati in altro modo ma in realtà il suo intento mirava ad esorcizzare, attraverso la metafora dell'arte, le inquietudini che, nel suo sentire, rimanevano nella memoria.

Nonostante le avversità la Lai tornò caparbiamente per diversi mesi a Camerino sperando che la sua idea venisse accettata. È stato probabilmente in una di queste occasioni che, forse per sfida, forse perché presumibilmente era il luogo più significativo, espose i varani che intanto aveva cucito nel cortile del palazzo ducale facendo scattare una foto (fig. 5b). In definitiva, l'epilogo di quest'opera fu, paradossalmente una 'disfatta' sia per l'artista che ne rimase ferita, sia per la città. Un sentimento che, a detta della Santarelli, si sente ancora oggi. 
Fig. 5. Sopra: i tre Varano cuciti da Maria Lai con scarti di stoffe (insieme e dettagli); centro: i varani cuciti appesi nel cortile del Palazzo Ducale; sotto: i varani nella casa di Maria Lai a Roma. Alcuni siti di Camerino in cui si suppone la Lai pensasse di esporre altri varani cuciti.
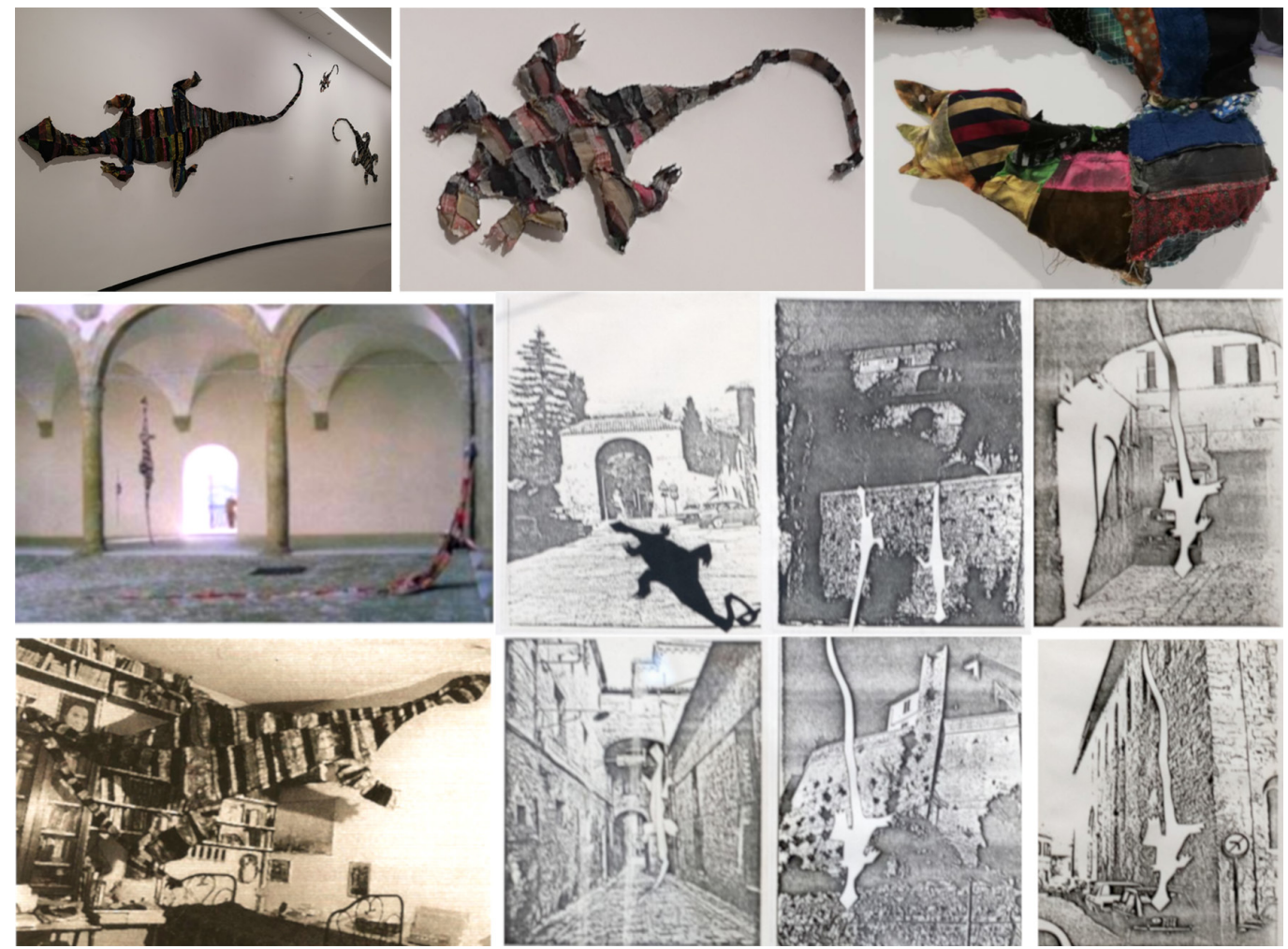

\section{Dedica ad Antonio Gramsci tra poesia e scultura}

L'opera Fiabe intrecciate (2007), posta negli spazi all'aperto della Stazione dell'arte a Ulassai, è una delle ultime sculture della Lai realizzata per il settantesimo anniversario della morte di Antonio Gramsci con il quale condivideva l'idea dell'importanza di avvicinare la gente all'arte ovvero della sua funzione educativa.

Il titolo scelto per l'opera nasce da una connessione tra due narrazioni simboliche: il racconto II topo e la montagna che Gramsci scrisse in carcere per il figlio Delio e la legenda della bambina col nastro che ispirò la performance Legarsi alla montagna. La reinterpretazione della Lai parte da un libro che giace al suolo, pesante come pietra, da cui esce, leggero, un nastro che vola verso la montagna. Nella storia un topolino affamato ha sottratto il latte ad un bambino povero e intende risarcirlo. Ma il topolino incontra una serie di personaggi che lo aiutano solo in cambio di altrettanti favori: la capra darà il latte se avrà erba, quest'ultima vuole essere irrigata e così via, sino a che non si rivolge alla montagna promettendo che quando il piccolo sarà cresciuto la ricompenserà piantando nuovi alberi e la bambina le offrirà il nastro celeste per legare a lei gli uomini e le case del paese di Ulassai in segno di pace [Ladogana 20।4, pp. 25-29]. Quindi nella sommità della scultura il bambino ha tra le mani un ramo verde e la fanciulla, portando il nastro, trasfigura la pesantezza iniziale in leggerezza e riscatto.

La scultura, alta quasi sei metri, è costituita da sottili tubi di acciaio inossidabile che, in una dimensione segnica, materializzano un disegno tridimensionale 'a fil di ferro' nello spazio offrendo allo sguardo un senso di leggerezza. Nel far prevalere i vuoti, attraverso i quali a seconda del punto di vista si intravedono montagne, cielo, verde e orizzonte verso il mare, la Lai realizza come un innesto dello spazio nella forma che comunica una volonta di unirsi al territorio (fig. 6). L'artista, che dal 1943 al 1945 aveva studiato con Arturo Martini all'Accademia di Belle Arti diVenezia dimostra con quest'opera non solo di aver custodito la lezione martiniana che professava per la scultura la liberazione dall'ossessione del volume ma altresì di averne saputo cogliere l'essenza. 
I personaggi della fiaba (il topo, la capretta, i sassi, il bricco di latte e i bambini), che si inerpicano lungo le 'ossa' della montagna, conservano tutta la forza delle capacità di disegnatrice dell'artista (fig. 7). Sono sagome grafiche ritagliate nel metallo, figure concepite nell'accezione sintetica di un segno di puro contorno dove la costruzione delle forme è affidata a un processo di riduzione e semplificazione. Tutte queste figure svolgono un ruolo nella definizione del ritmo dell'insieme, ne scandiscono i momenti narrativi dando all'opera una dimensione musicale (fig. 8). In ciò, e anche nella capacità di trasformare storie in stratagemmi per guardare il mondo, si ritrova invece l'insegnamento dello scrittore Salvatore Cambosu, suo professore di Italiano e Latino alle scuole secondarie, che quando era bambina le diceva "non importa se non capisci, segui il ritmo". In questa scultura il ritmo si fa ascensionale e da poetico diviene forma visiva che svolge l'intreccio tra il racconto di Gramsci e la leggenda di Ulassai.
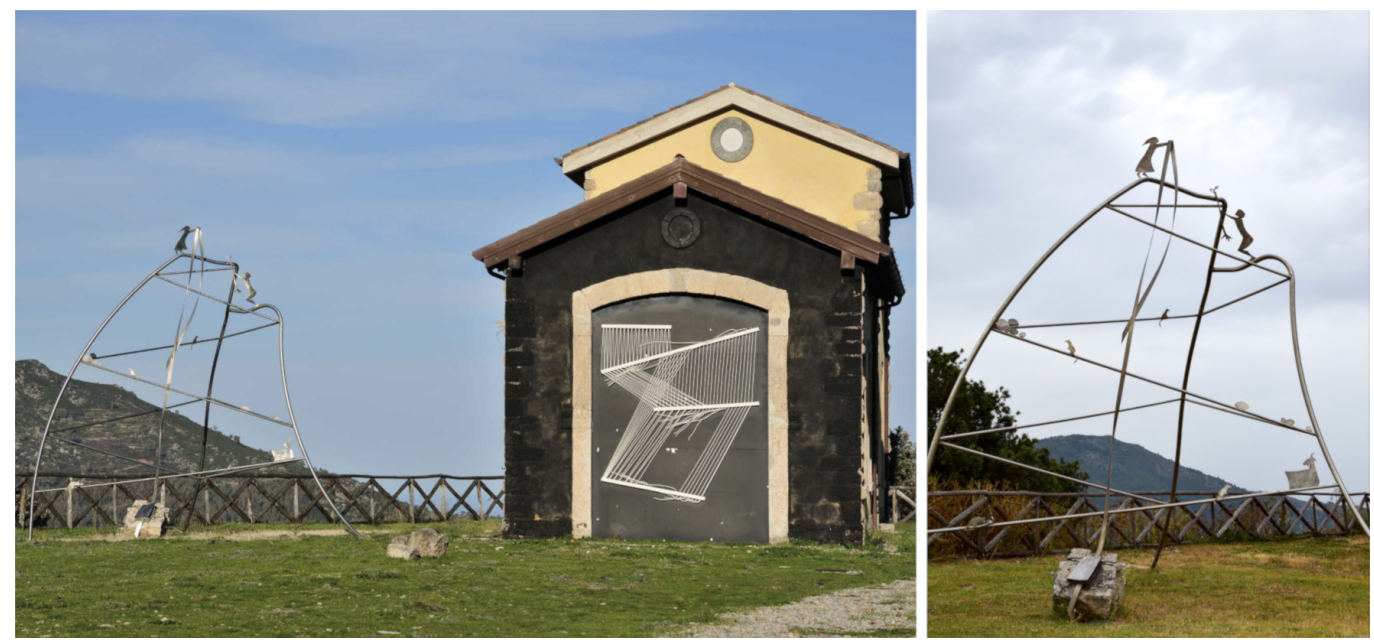

L'opera sembra riconnettere tutte le persone e gli elementi che hanno segnato la vita e il modo di concepire l'arte della Lai: origini, tradizione, poesia, scultura, disegno. L'artista trasforma il racconto in una 'fiaba sociale' contemporanea servendosi di figure esemplari per raccontare cose tremende: povertà, guerra, incuria della natura, principi di do ut des. Ma dalla constatazione del negativo propone una strada di leggerezza che cancella ancora una volta le distanze tra passato e presente; unisce quegli estremi del 'gioco' tra universale e particolare, tra spazio e tempo, saldando il tempo indefinito della fiaba al tempo presente della vita perché le legende "sono come bozzoli che contengono significati universali" [Lai 20I I].
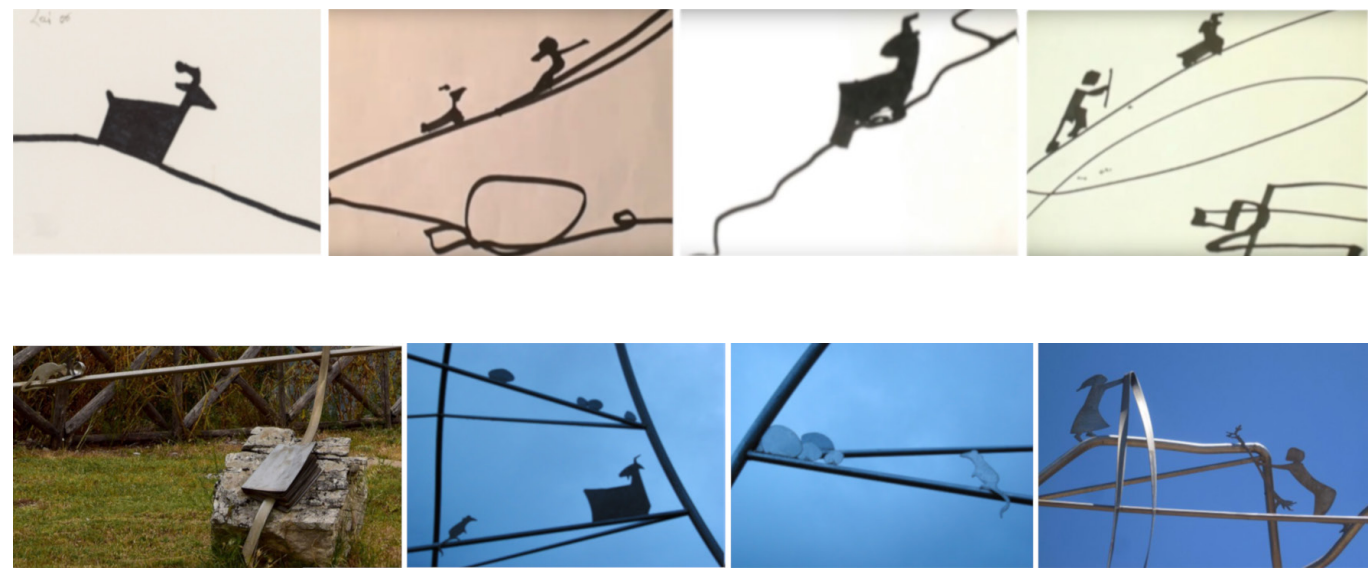


\section{L'arte della tessitura come affermazione di contemporaneità}

Maria Lai interviene in un borgo dell'alta Gallura, Aggius, nel luglio del 2008, dove è presente una millenaria tradizione artistica della tessitura del tappeto con il telaio a mano. Relazionandosi concettualmente a Legarsi alla montagna, Maria Lai organizza Essere è tessere, come un'opera che possiamo definire di 'glocal walkabout'. Durante questo evento l'artista predispone una serie di giochi e performance sociali, nei quali viene spiegata l'arte della tessitura da alcune fanciulle con la finalità di 'riconnettere' gli abitanti di Aggius alla loro tradizione.

Il duale rapporto col passato e con la contemporaneità, caratteristica distintiva della ricerca artistica della Lai, rende l'opera accessibile ai linguaggi dell'oggi e contemporaneamente risulta radicata alla storia della Sardegna. Dai telai nascono le tele cucite, che da un lato continuano a evocare il mondo arcaico dell'arte tessile della Sardegna - in cui la forma più antica di linguaggio si traduce in disegno, in tratto tridimensionale fatto di filo e di tessuto - dall'altro le opere si inseriscono in quella ricerca espressiva che lavora non sulla tela ma 'con' la tela, dialogando per forza di cose con i 'polimaterici' di Prampolini, i 'sacchi' di Burri, le 'tele fasciate' di Scarpitta, i 'tessuti irrigiditi dal caolino' di Piero Manzoni, le tele di Bonalumi e Castellani o quelle vuote di Dadamaino.

L'evento, seguendo il personale approccio artistico di Maria Lai, coinvolge l'intero paese in una sorta di gioco attraverso un percorso che come una processione si snoda tra i vicoli del borgo. Mediante una linea d'azione ludico-partecipativa il fine ultimo è promuovere esperienze per raccogliere storie e divulgare tradizioni del magnifico territorio sardo. Con partenza da Parco Alvinu, accompagnato dalla recitazione di testi appositamente ideati per l'occasione dalla stessa Lai, l'itinerario arriva nelle piazze del centro storico nelle quali si svolgono le diverse attività, fino a giungere in piazza del Rosario, punto conclusivo del percorso (fig. 9). I bambini, guidati da due attrici, un angelo e una fata dell'arte, recitano le filastrocche della Lai e prendono parte al Gioco dell'oca, altra creazione disegnata interamente dall'artista; poi l'itinerario prosegue fino a piazza della Campana dove da un balcone una ragazza intona una ninna nanna in dialetto corso-gallurese e l'attore Michel Rocher decanta una poesia di Withman [Pioselli 20 I5, pp. I03, I04].

Mentre i bambini vengono coinvolti con giochi e filastrocche, le donne del luogo mostrano, nelle dieci stazioni del percorso, le fasi della filatura della lana, dalla stesura dell'ordito

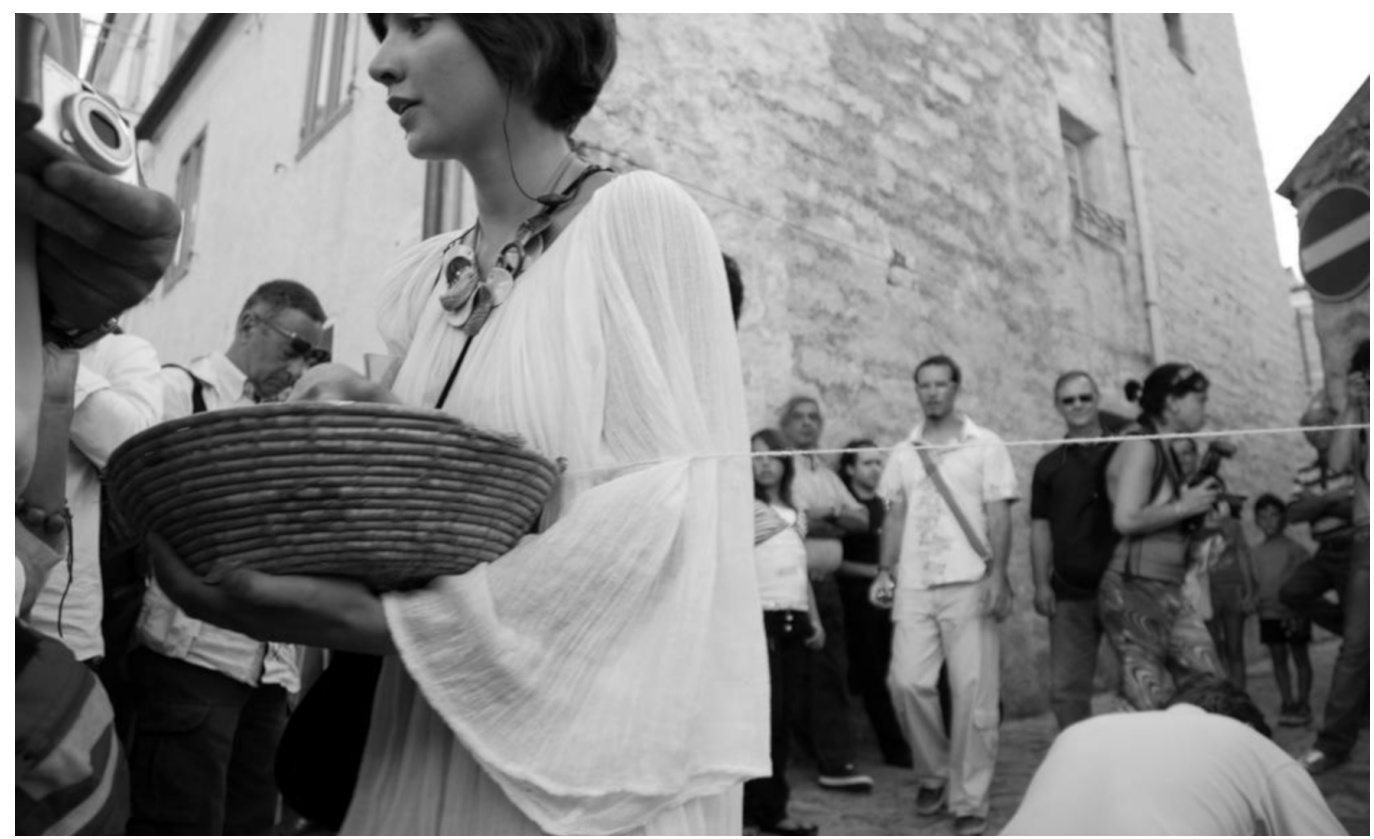


alla tessitura, circondate, come scenografia, dalle installazioni di Maria Lai dislocate negli stessi ambienti: arazzi stilizzati e dipinti, frasi criptiche e lettere dell'alfabeto ricamate a colori, caprette in miniatura scolpite o ricamate o dipinte sui muri, ma soprattutto i quattordici telai metallici stilizzati in alluminio esposti su pannelli dai diversi colori - ancora oggi appesi sulle mura delle case a ricordo dell'evento - cambiano radicalmente il volto del paese (fig. I0).
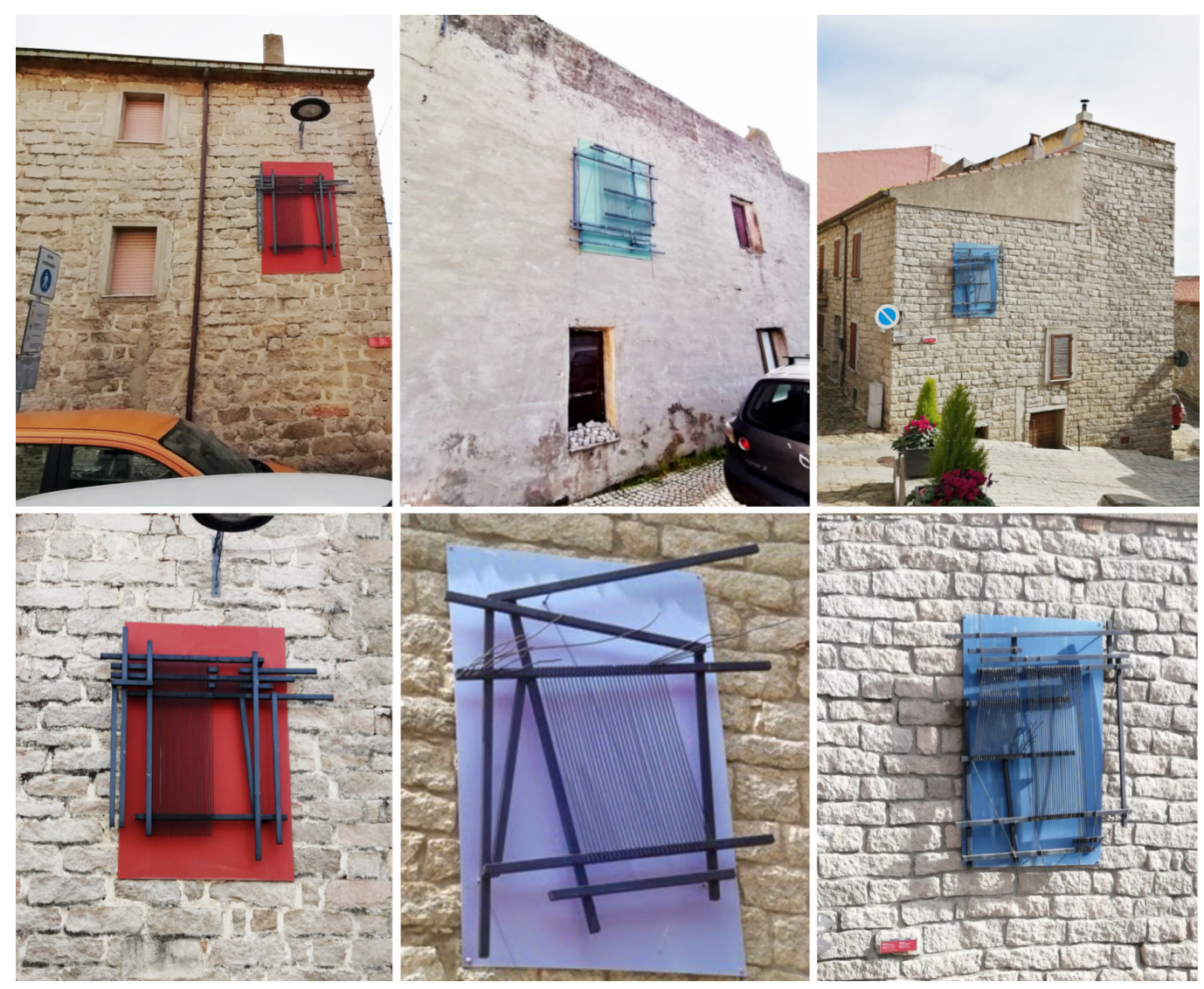

Durante la performance gli abitanti si incontrano tra di loro e si relazionano trovando il senso di essere una comunità attraverso l'archetipo del telaio. Vero cardine dell'iniziativa è infatti la tessitura, la cui importanza per Aggius è insita nel titolo dell'opera Essere è tessere, una dichiarazione di identità congiunta all'attuale. Non c'è un ricordo nostalgico delle pratiche produttive del passato e nemmeno una esaltazione del folklore coniugato a tale artifizio tradizionale, bensì un'affermazione di contemporaneità. La Lai compie una operazione di disegno invisibile sulla città, tracciando dei percorsi e lasciando delle impronte che ridefiniscono l'aspetto urbano senza snaturarne l'aspetto abituale, in cui la tradizione locale viene promossa mediante una esperienza pratica ed estetica ma soprattutto percepita nel presente in modo talmente energico da definirne l'essenza stessa del luogo (fig. I I). II legame strettissimo tra tradizione e territorio è così emerso durante tutta l'operazione, chiaro indizio ne è stata la volontà di situare il progetto Essere è tessere direttamente tra i vicoli e le piazze del paese ospitando persone, artefatti, telai, in sintesi la cultura di un'intera comunità [Battista, Saragato 20I6]. 
Fig. I1. Interazione dell'artista con le donne del luogo, le filatrici.

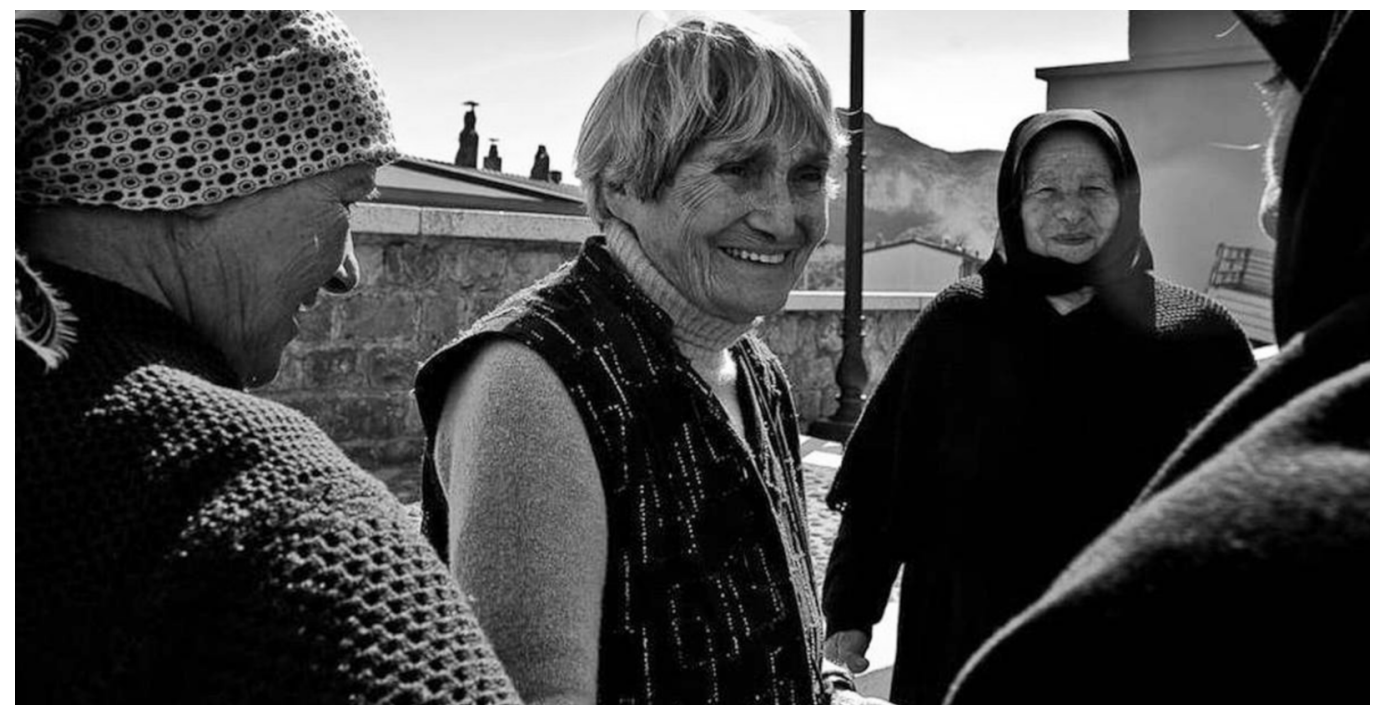

\section{Conclusioni}

La Lai non è stata una donna distante dalla realtà. Benchè si definisse un'eterna bambina che giocava ma con grande serietà, non si è nascosta nella fantasia, al contrario, la sua sensibilità artistica l'ha portata a maturare una profonda consapevolezza della necessità di coltivare le differenze nella convivenza, di saper interpretare la democrazia [Boldrini 20 I 3].

La sua opera attesta una rara capacità di connessione tra tradizione e contemporaneità, di attitudine nel saper ricucire il passato (memora ancestrale) con il presente (istanze di attualità) trasformandolo in occasione di nuova conoscenza e di proiezione verso un futuro che coniuga insieme particolare ed universale [Moschini 20 I8].

Attraverso un percorso di esemplare coerenza e di consapevolezza del valore sociale dell'arte, Maria Lai è stata una donna che oggi definiremmo resiliente. Ha realizzato tanti interventi ambientali [I] da vivere e da 'leggere' che, nel lasciar coabitare diversi livelli di lettura, mirano a rifondare un vocabolario visivo e concettuale che rivendica alla narrazione una capacità di significazione. E forse il murales di $35 \times 5$ metri realizzato negli spazi sportivi del CUS Cagliari (2016), street art corale [2] di intreccio narrativo-visivo dedicata alla poetica della Lai, testimonia come la sua eredità sia sentita dalle nuove generazioni (fig. 12).

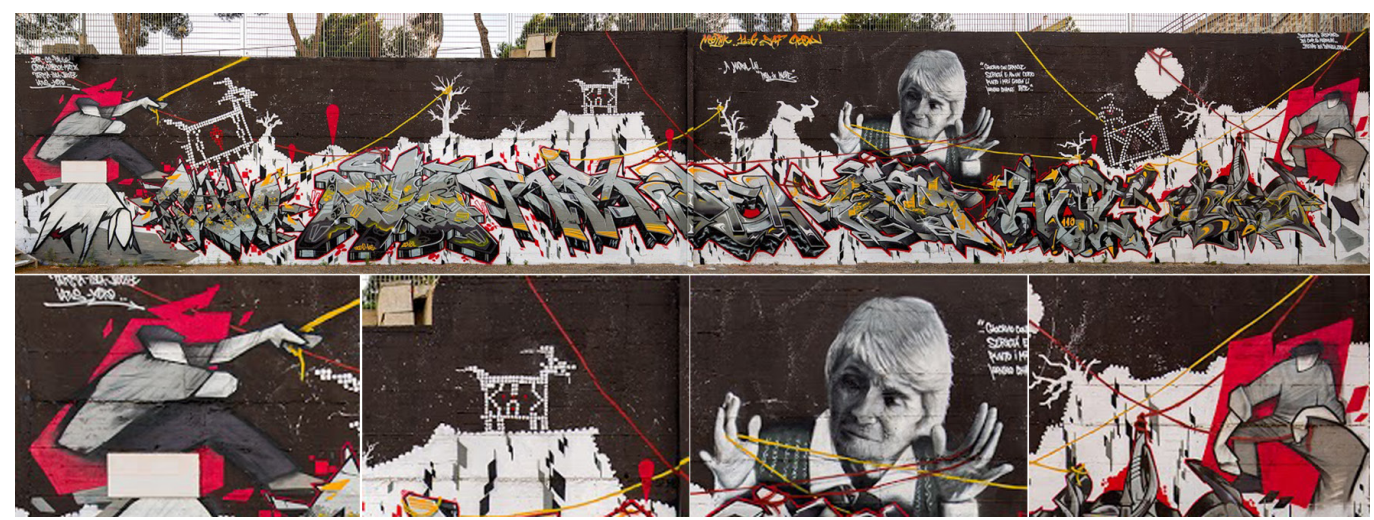

Note

[I] A Ulassai:Telaio del lavatoio (1 982), La strada del rito e Le capre cucite (1992), La scarpata (1993), Paesaggi (1996), Scultura sonara e Cà de Janas (1997), Il gioco del volo dell'oca (2002), La lavagna (2003), II muro del groviglio (2004), La casa delle inquietudini (2005), Libretti murati (2005), Pastorello mattiniero con capretta (2005); opere di preludio all'apertura della Stazione 
dell'arte (2006). Sempre in Sardegna: Reperto (1982, Villasimius), L'alveare del poeta (1984, Orotelli), L'albero del miele amaro (1997 Siliqua), La cattura dell'ala del vento (2009, parco eolico di Ulassai), Andando via (20I2, Nuoro, monumento a Grazia Deledda).

[2] Crew: Sardos Frades Crew, Undici Sei Squad, Neo-Ink. Foto di Francesco e Daniele Brotzu. @[20 I6] by Giuseppe Moro Grim: <http://grimdcc.blogspot.it>

\section{Riferimenti bibliografici}

Battista Maria Grazia, Saragato Mario (a cura di). (2016). Un paese che racconta. Aggius: Phileas.

Birrozzi Carlo, Pugliese Marina (2007). L'arte pubblica nello spazio urbano. Committenti, artisti, fruitori. Milano: Bruno Mondadori

Boldrini Laura (Presidente della Camera dei deputati), 2013. Intervento al Convegno "Maria Lai - L'arte tra gioco e magia", Roma, Palazzo Montecitorio, (17.10.13): <https://www.youtube.com/watch?v=cbV4fmcT0Qw>

Bourriaud Nicolas (2010). Arte relazionale. Milano: Postmedia Books. Traduzione di Marco Enrico Giaconelli. (Edizione originale 1998, Esthétique relationnelle. Dijon: Les presses du réel).

Capulli Maria Grazia (1984). L'artista del varano. In L'Appennino Camerte, n. 44, pp. 2.

Cuccu Giuseppina, Lai Maria (2002). Le ragioni dell'arte. Cose tanto semplici che nessuno capisce. Cagliari: Arte Duchamp.

Guerra Medici Maria Teresa (2002). Famiglia e potere in una signoria dell'Italia centrale: i Varano di Camerino. Camerino: Università degli Studi.

Ladogana Rita (20|4). «Fiabe intrecciate». La scultura di Maria Lai dedicata ad Antonio Gramsci. In Terra Gramsci (a cura di). Maremuro. Appunti per un dialogo realmeraviglioso. Maria Lai in dialogo con Antonio Gramsci. Cagliari: CUEC, pp. 25-29.

Lai Maria (1988). Da una conversazione tra Maria Lai e Mario De Candia, Roma, 20 novembre 1986. In Ciusa Maria Elvira Bua Mimmo, De Candia Mario, Zaru Francesca A. A matita: disegni di Maria Lai dal 194I al 1985. Milano: Franco Maria Ricci per Arte Duchamp.

Lai Maria (1984-2004). Tenendo per mano il sole. <https://www.youtube.com/watch?v=G3_wA3Wg5js>; <https://www.maxxi. art/events/maria-lai-tenendo-per-mano-il-sole/>.

Lai Maria (2005). L'isola delle storie: <https://www.youtube.com/watch?v=T4EPJRQDe9M>.

Lai Maria (20I I). Inventata da un Dio distratto - parte I. <https://www.youtube.com/watch?v=TL8mGWVreel>.

Moschini Francesco (20/8). Intervento alla "Presentazione volume Maria Lai. Arte e relazione di Elena Pontigia", Roma, Accademia di San Luca, (27.03.20 I 8): <https://www.youtube.com/watch?v=R600fQeBzql>.

Paino Fiorella (200 I). D'azzurro o di verde? Note sull'insegna araldica dei da Varano di Camerino. In De Marchi Andrea, Falaschi Pierluigi (a cura di). I da Varano e le arti. Atti Del Convegno internazionale Camerino. Palazzo Ducale 4-6 Ottobre 200 I, vol. I, pp. 109-124. Ripatransone: Maroni.

Pioselli Alessandra (20I5). L'arte nello spazio urbano. L'esperienza italiana dal 1968 a oggi. Monza: Johan\&Levi.

Pontiggia Elena (2017). Maria Lai. Arte e relazione. Nuoro: llisso.

Santarelli Vera (1984). II varano alle finestre? Era solo una provocazione. In L'Appennino Camerte, n. 19 , pp. 2.

\section{Autori}

Alessandra Meschini, Università di Camerino, alessandra.meschini@unicam.it

Alessandro Basso, Libera Università di Bolzano, alessandro.basso@unibz.it

Per citare questo capitolo: Meschini Alessandra, Basso Alessandro (2020). Narrazioni visuali attraverso il tempo e lo spazio: trame e metafore di connessioni per lo spazio pubblico/Visual narratives through time and space: weaves and metaphors of connections for public space. In Arena A., Arena M., Brandolino R.G., Colistra D., Ginex G., Mediati D., Nucifora S., Raffa P. (a cura di). Connettere. Un disegno per annodare e tessere. Atti del $42^{\circ}$ Convegno Internazionale dei Docenti delle Discipline della Rappresentazione/Connecting. Drawing for weaving relationships. Proceedings of the 42th International Conference of Representation Disciplines Teachers. Milano: FrancoAngeli, pp. 3533-3552. 


\title{
Visual Narratives through Time and Space: Weaves and Metaphors of Connections for Public Space
}

\author{
Alessandra Meschini \\ Alessandro Basso
}

Abstract

Through analysis of some of selected works, this contribution addresses some aspects related to the multifaceted work of the Sardinian artist Maria Lai, who is considered one of the most dynamic and important minds in contemporary art. Her narrative language adheres to a poetry of connection among the elements that always leaves intact the multi-material sense and multiple meanings of the combined parts, first through the sign of stitching and then through outdoor works and activities of participatory art. Stressing that everything is connected -the present with the past, transverse knowledge with collective imagination- Lai expresses a perception of the sense of art that allows her to transform even an everyday object, designed to be aesthetic but also functional, into a poetic object, into a 'generator of reflection' capable of teaching us to dream and remember.

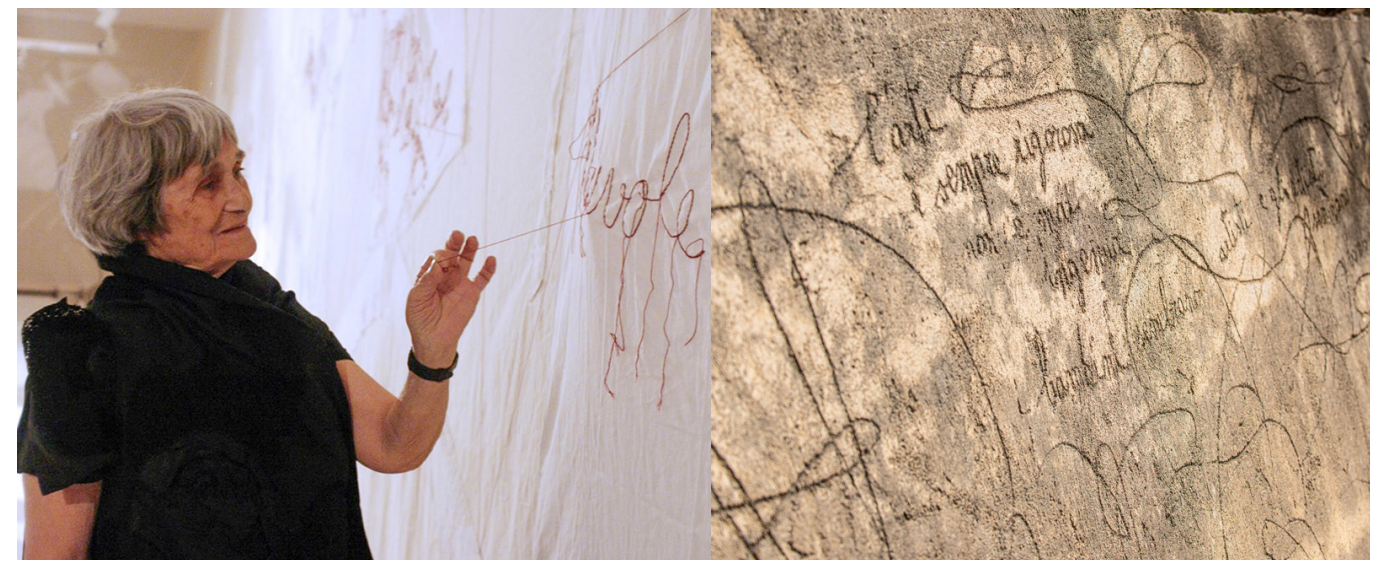




\section{Introduction}

Tie, connect, sew, weave, join, involve, relate, share, participate, but also outline, warp, collage, mesh, narrative: verbs 'in the infinitive' and nouns that are very 'representative' of the poetry of Maria Lai, a Sardinian artist who has made connections on various levels the theme of her living, research, and work.

A woman with international reach and one of the most interesting figures in the history of Italian art following the Second World War although only duly recognized after her death, she always worked in a solitary, reflexive dimension, favouring silence over clamour.

Fig. 1. Telaio in sole e mare (1971); tela cucita, A Luisa (1975); sewn fairy, Le magie di Maria Pietra (1983); Geografia per Giuliana (1997); Lenzuolo cucito (2007); sewn book Le parole imprigionate (2008).
Fig. 2. The environmental installation Casa Cucita (1979) in Selargius: basting on the external wall sting on the
of a building.
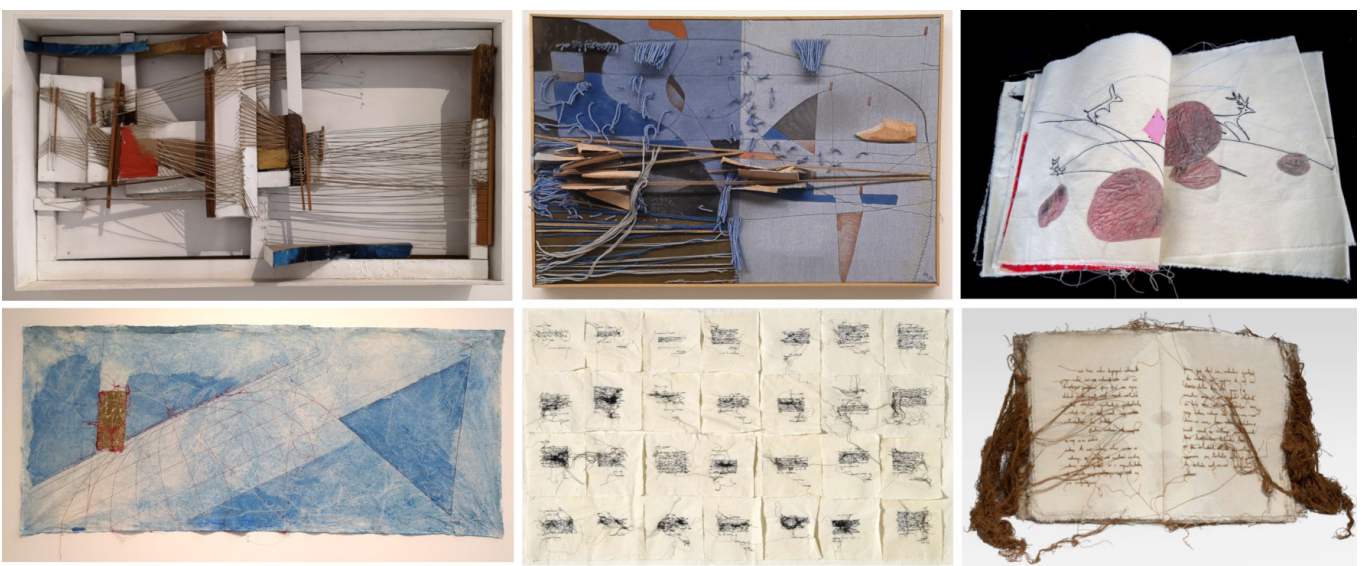

Her art, defined by many as conceptual but defying any classification, is imbued with her island roots, built on memories of artisan crafts and ancient oral narrations learned in infancy. In fact, while an excellent designer and sculptor, starting in the 1960s, she began to "look at art from many different points of view, all of those that could be suggested" [Lai 2005]. Substituting pencil with needle and working with fabrics and materials in which the thread becomes a sign, she created works - multi-material looms, sewn fabrics and tales, sewn books and sheets, geographies (fig. I) - that aims to reconcile materials and forms where the thread "that unites places and intentions" [Lai 1984-2004] -weaving in the dual material and conceptual meaning- becomes a metaphor for connection, places, and traces of thought, memory [Cuccu, Lai 2002 p. 19], and therefore a basis on which to develop infinite variations.

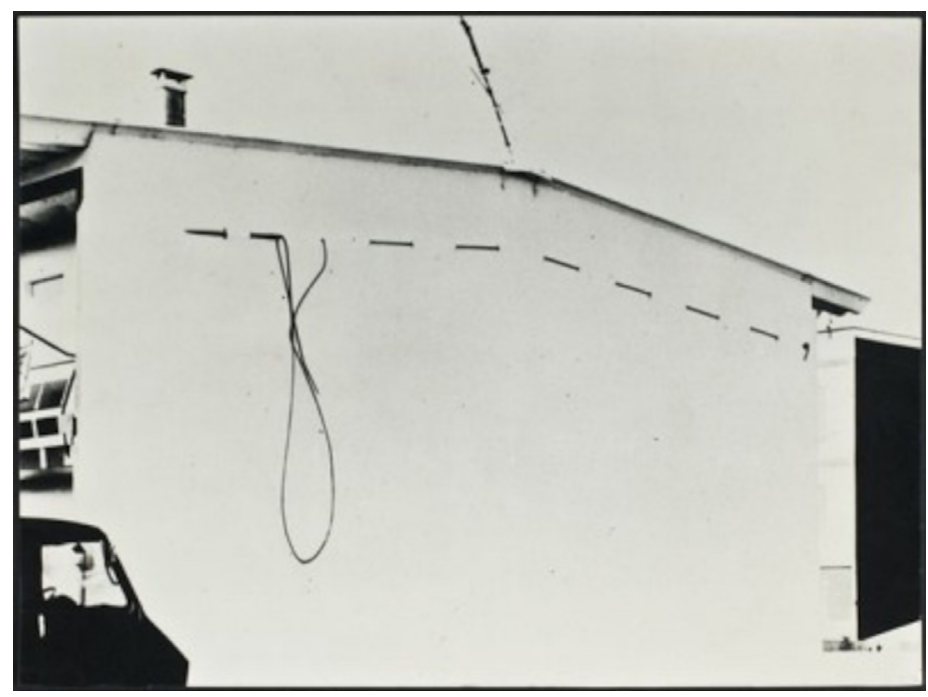


Fig. 3. The testimony of Legarsi alla montagna recorded in a series of black and white photos by Piero Berengo Gardin then coloured by the artist.
In the 1980s, anticipating what would then be defined as "relational aesthetics" [Bourriaud $2010]$ and differentiating it from Land Art and Public Art, she began to conceive interventions for public space in the form of both actions of shared creativity and permanent art immersed in the landscape, developing a practice of dialogue in which the thread becomes a symbol of a new ability to communicate, creating links between people, places, and history [Birrozzi, Pugliese 2007, pp. 3 I-35; Pontiggia 2017, p. I 5 I].

The start of this phase came with the environmental intervention Casa Cucita (1979) -an outline on the exterior wall of a building in Selargius (fig. 2)- but bloomed fully with Legarsi alla montagna (198I). In this first work of relational art, she renews her own means and tells an ancient legend about a child who was miraculously saved from a landslide by following a blue ribbon (art). This work holds great importance for its anthropological/social value: a transformation of the landscape through which the perception of places is reconfigured, sanctioning a reconciliation between a dry, hard, wild land and a community of people who have seemed to stop loving it (fig. 3).

Focusing on her later production and addressing various meaningful works, this article highlights the relationships between Lai's art and themes of visual communication and narration, that is, the tie established between creative language and thought on the perceptual level.
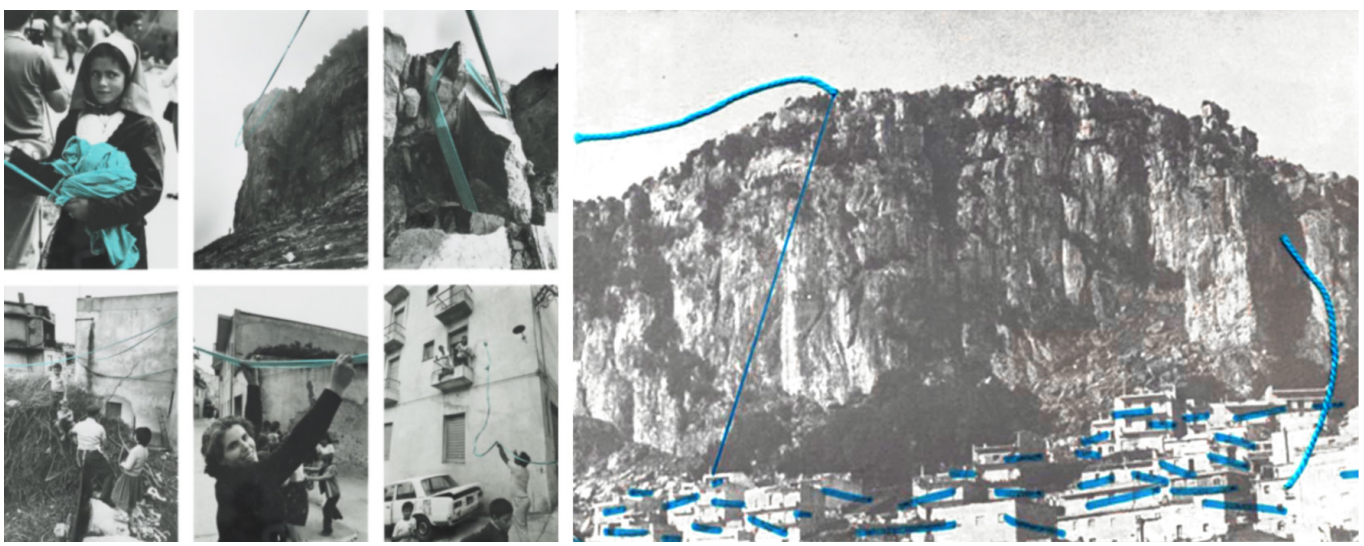

\section{Camerino and the metaphor of the Varanus}

The work La disfatta dei varani (1983), which is always cited but in reality little documented, was a project strongly felt by Maria Lai though it was never realized. To deepen the study of the work, an interview was made with the Councillor for Culture of Camerino at the time, Vera Santarelli, that is, the one who proposed Lai to Camerino, followed the artist in numerous encounters aimed at realizing this work of collective action, and witnessed the events. The title of the work itself contains the complicated network of connections that the artist had identified, both the origin of the refusal to the realization of the performance. First, two aspects of the history of Camerino struck Lai's imagination. On the one hand, there was the image of a family, the Da Varano (lords of the city for nearly 300 years), torn apart by a fratricidal war (slaughter of the Varano) due to internal fighting for power [Medici 2002]; on the other hand was the depiction of a 'sea dog', sometimes also represented as a winged dragon with a scaly body, contained in the crest of the historical coat of arms of Giulio Cesare Da Varano killed with his three sons by Cesare Borgia in 1502 [Paino 200 I, pp. I09124]. Lai probably associated this mythological figure with one of the largest living reptiles, the Komodo dragon or 'varanus'. The artist also embraced other suggestions from within the narrow alleys of the medieval footprint of the city, from the toponym of the Le Conce quarter, which suggested the idea of the skin, to the topographic image of the city whose elongated form still echoed the shape of a lizard [Santarelli 1984, p. 2] (fig. 4). 
Tying together all these images, Lai created the title's 'play' on words, explaining: "what struck me about Camerino was the sense of the labyrinth within the city [...]. The dominant architecture [...] gives the urban space a sense of terribilità" [Capulli I 984, p. 2] of the city "that has suffered due to fights, wars, destruction, and human and natural violence, but which has always managed to rise again" [Lai 1988, p. 23]. "I therefore developed an image that contains both wonder and fear [...]. The image concentrates on the skin" [Capulli 1984, p. 2], "a symbolic trophy of a victory of man against the "beast', against himself, against adversity" [Lai 1988, p. 23].
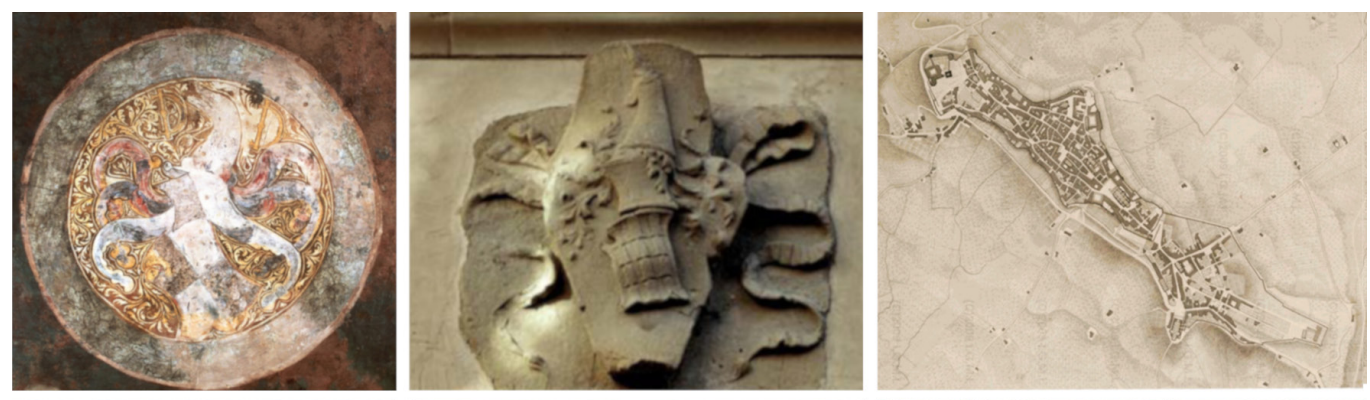

Fig. 4. Signs of Giulio Cesare da Varano at the Palazzo Ducale in Camerbride and groon's rom bride and groom's room, stone coats of arms in the quadriportico. Decorative detail on the portal of the church of San Francesco in Camerino. Historical map and current zenithal view
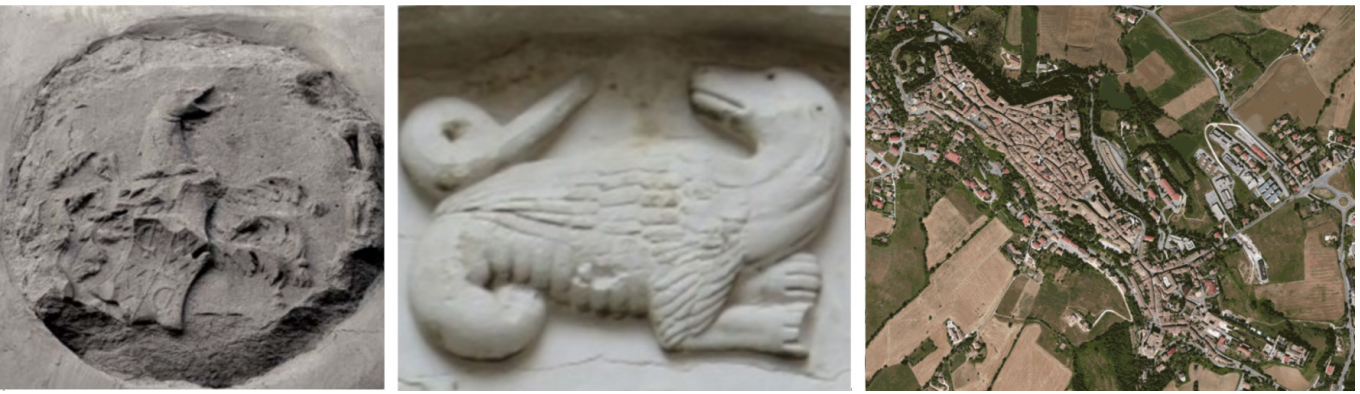

The project foresaw a unanimous operation involving all schools and associations in the city. Children and teenagers would have made lizards out of tissue paper that, tied to white balloons, would have all been let go at the artist's signal. Meanwhile, revisiting the tool of sewing as a metaphor for dialogue among diversity, she would have created large lizards with the use of a patchwork of basic fabrics (fig. $5 \mathrm{a}$ ) with the idea of placing them at various points around the city. To document the performance, Lai had engaged, as at Ulassai, the photographer and RAl operator Piero Berengo Gardin. The overall intent was to begin a promotion of art in the territory that would occur every two years.

Unfortunately the directorate of schools, associations, and city administration could not enter the logic of the initiative. On the contrary, they viewed the contrasting juxtaposition with the animal lizard as an offence to the historical greatness of the city. Lai had certainly touched on aspects of Camerino's history that perhaps would have preferably been told in another way, but in reality her intent was to use the metaphor of art to dispel the anxiety that, in its feeling, had remained in memory.

Despite this adversity, Lai stubbornly returned to Camerino for several months, hoping that her idea would be accepted. It was probably on one of these occasions that, perhaps because of the challenge, perhaps because it was presumably the most meaningful place, she exhibited the lizards that she had already sewn in the courtyard of the ducal palace, taking a photo of it (fig. 5b). Ultimately, the epilogue of this work was, paradoxically, a 'defeat' both for the artist, who remained hurt, and for the city; a feeling that, according to Santarelli, is still felt today. 
Fig. 5. Above: the three Varanus sewn by Mari Lai with fabric scraps (together and details); centre: the sewn varans hanging in the courtyard of the Ducal Palace, the varanus in Maria Lai's house in Rome some sites in Camerino where Lai is supposed to exhibit other sewn varanus.
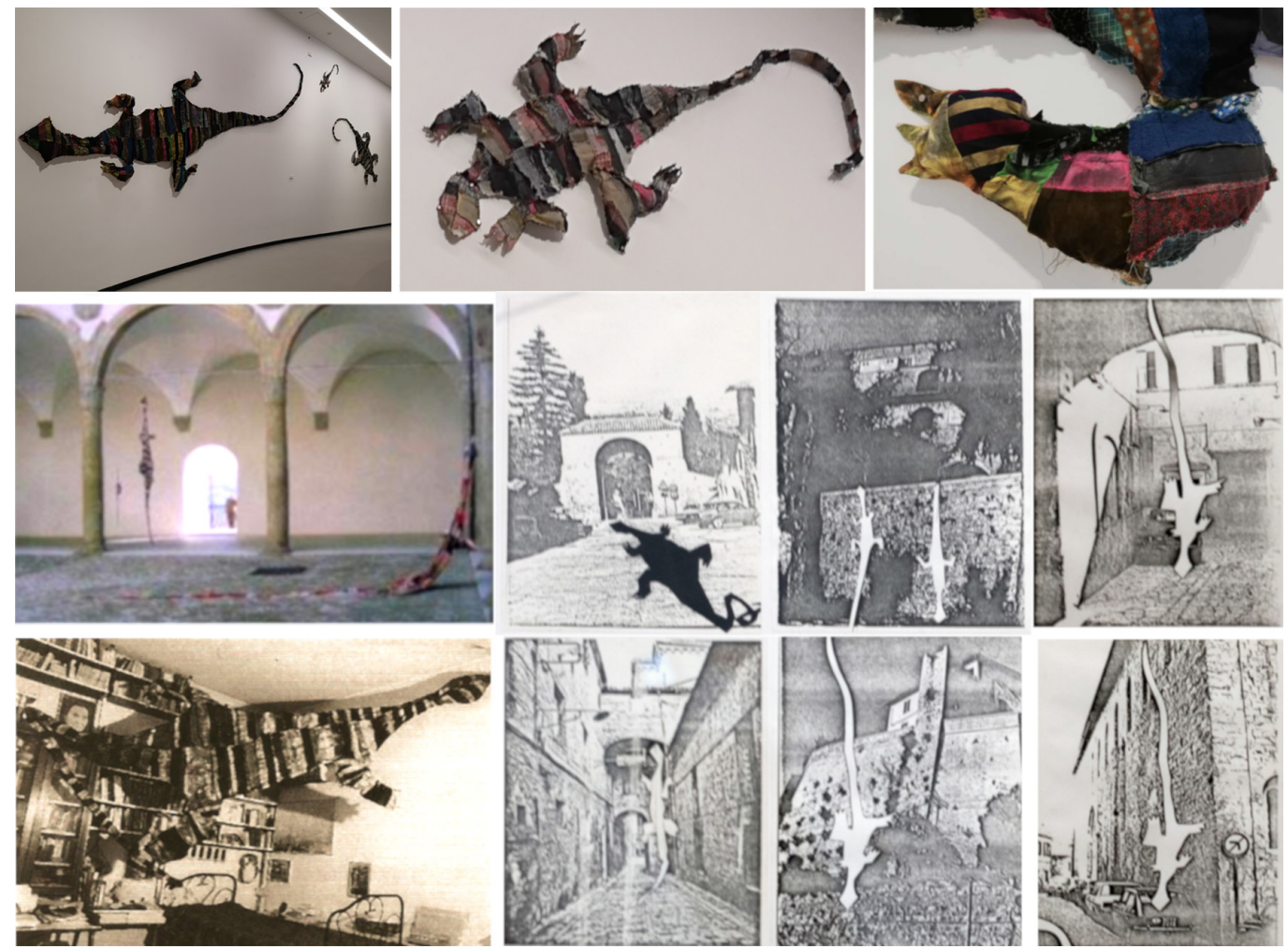

\section{Dedication to Antonio Gramsci, between poetry and sculpture}

The work Fiabe intrecciate (2007), situated in the open space of the Stazione dell'Arte in Ulassai, is one of the last sculptures Lai made for the seventieth anniversary of the death of Antonio Gramsci with whom she shared the idea of the importance of bringing people to art, that is, its educational function.

The title chosen for the work grew out of a connection between two symbolic narratives: the story II topo e la montagna that Gramsci wrote in prison for his son Delio and the legend of the child with the ribbon that inspired the performance Legarsi alla montagna. Lai's reinterpretation begins with a book that lies on the floor, heavy like a stone, from which rises a nearly weightless ribbon that flies towards the mountain. In the story, a hungry mouse takes milk away from a poor boy, intending to pay it back. But the mouse meets a series of characters that agree to help it only in exchange for other favours: the goat gives milk if he gets grass, the latter wants to be watered, and so forth, until they address the mountain, promising that when the boy grows up, he will repay it by planting new trees and the girl will offer the blue ribbon to tie the people and houses of the town of Ulassai to her as a sign of peace [Ladogana 20 I4, pp. 25-29]. At the top of the sculpture the boy holds a green branch in his hands and the girl, holding the ribbon, transforms the initial weight into lightness and release. The sculpture, nearly six metres high, is made of thin tubes of stainless steel that, as a sign themselves, create a three-dimensional 'line' drawing in the space, presenting a sense of lightness. In making space prevail, through which one sees mountains, sky, greenery, and horizon to the sea depending on the point of view, Lai inserts space into the form, communicating a desire to be united with the territory (fig. 6). The artist studied with Arturo Martini at the Accademia di Belle Arti in Venice from 1943 to 1945, and with this work she shows not only that she guarded his lesson that sculpture be freed from the obsession of volume, but also that she knew how to gather its essence.

The characters in the fable (the mouse, goat, stones, milk jug, and the children) clambering along the 'bone' of the mountain, store all the strength of the artist's drawing skils (fig. 7). 
They are graphical profiles cut into the metal, figures designed in the synthetic acceptance of a sign of pure outline where the construction of the shapes is entrusted to a process of reduction and simplification. All these figures play a role in defining the rhythm of the whole; they articulate the narrative moments, giving the work a musical dimension (fig. 8). This, as well as Lai's ability to transform stories into stratagems to guard the world, also illustrate the teaching of the writer Salvatore Cambosu, her secondary school Italian and Latin teacher, who told her when she was young, "it doesn't matter if you don't understand, follow the rhythm". In this sculpture, the rhythm ascends and, from poetry, becomes a visual form that acts as braid Gramsci's story with the legend of Ulassai.

The work seems to reconnect all the people and elements that have marked Lai's life and her way of conceiving art: origins, traditions, poetry, sculpture, drawing. The artist transforms the story into a contemporary 'social fable', using exemplary figures to relate tremendous
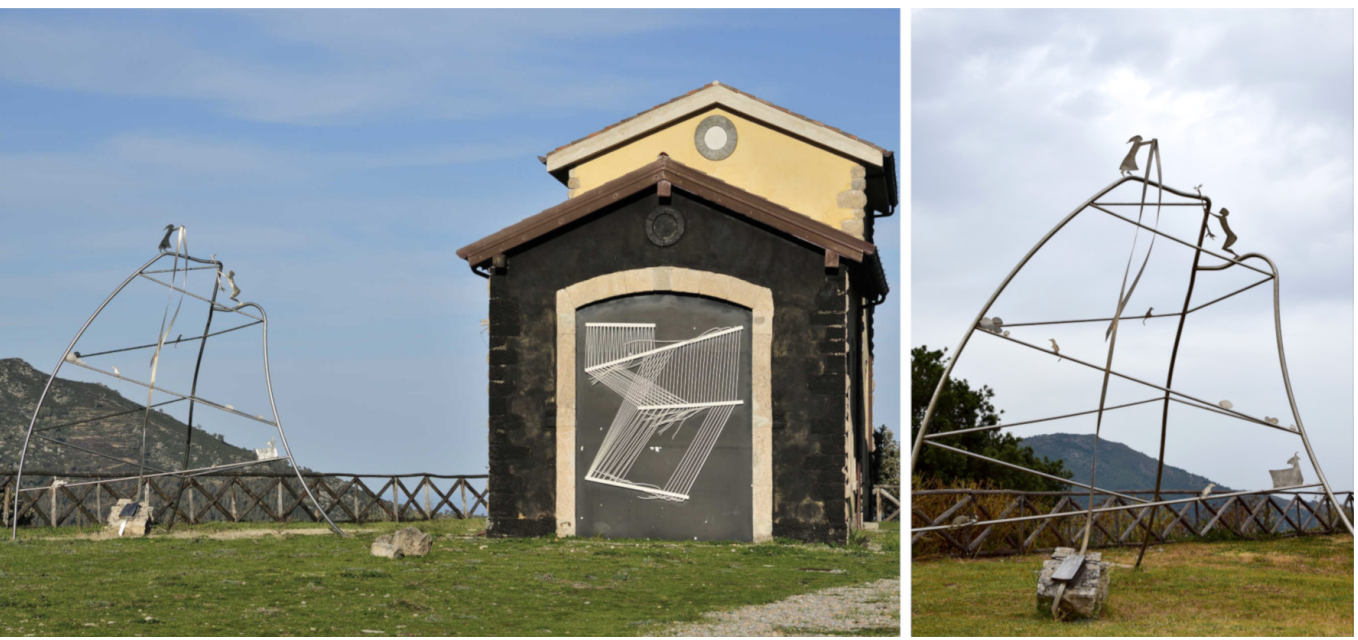

things: poverty, war, neglect of nature, the principles of do ut des. But by verifying the negative, she proposes a road of lightness that once again eliminates the distances between past and present. She unites the ends of the 'game' between universal and particular, between space and time, welding the indefinite time of the fable to the present time of life, because legends "are like cocoons that contain universal meanings" [Lai $20 \mathrm{l} \mathrm{I].}$
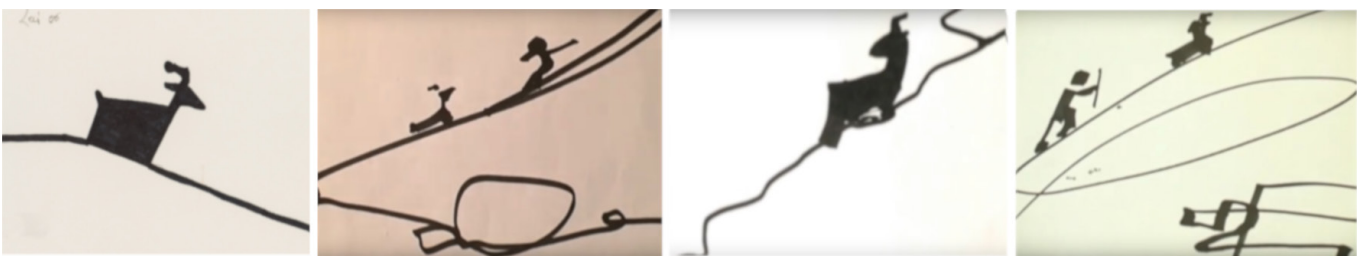

Fig. 7. Some drawings by Maria Lai: La capretta (ink on paper), studies for
the fairy tale II pastorello (marker on paper).
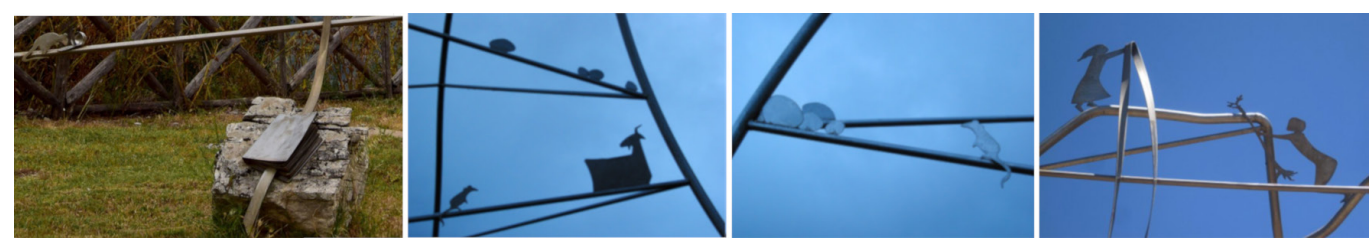


\section{The art of weaving as an affirmation of the present}

Maria Lai intervened in a town of upper Gallura in July 2008 -Aggius- which has an ancient artistic tradition of hand-weaving rugs with looms. In conceptual relation to Legarsi alla montagna, Maria Lai organized Essere è tessere as a work that could be defined as 'glocal walkabout'. During this event, the artist prepared a series of games and social performances in which the art of weaving was explained by some young girls with the aim of 'reconnecting' the inhabitants of Aggius to their tradition.

The dual relationship with the past and present, a defining characteristic of Lai's artistic search, makes the work accessible to the languages of today and is simultaneously rooted in the history of Sardinia. From the looms come sewn fabrics that both continue to evoke the archaic world of Sardinia's textile art - in which the oldest form of language translates into drawing, in a tri-dimensional line made of thread and fabric-, on the other hand the works are part of that expressive research that operates not on the canvas but 'with' the canvas, interacting through the strength of things with Prampolini's 'polimaterici', Burri's 'sacchi', Scarpitta's 'tele fasciate', Piero Manzoni's 'tessuti irrigiditi', Bonalumi and Castellani's canvases and Dadamaino's empty ones.

Following Maria Lai's personal artistic approach, the event involved the entire town in a sort of game, following a path that, like a procession, wound through the streets of the town. Along the lines of a playful/participatory activity, the ultimate goal was to promote experiences to gather histories and spread traditions from the magnificent territory of Sardinia. Starting at Parco Alvinu, accompanied by the reciting of texts designed precisely for the occasion by Lai herself, the route passed through the squares of the historical centre where the different activities were held, until it reached Piazza del Rosario, the end of the route (fig. 9). Children, guided by two actresses, an angel and an art fairy, recited nursery rhymes by Lai and took part in the Gioco dell'oca, another creation designed entirely by the artist. The route then proceeded up to Piazza della Campana where a girl on a balcony sang a lullaby in Corsican/Gallurese and the actor Michel Rocher read poetry by Whitman [Pioselli 20।5, pp. I03, I04].

While the children were involved with games and nursery rhymes, local women displayed the phases of spinning wool, the pattern of the warp and weave, at ten stations along

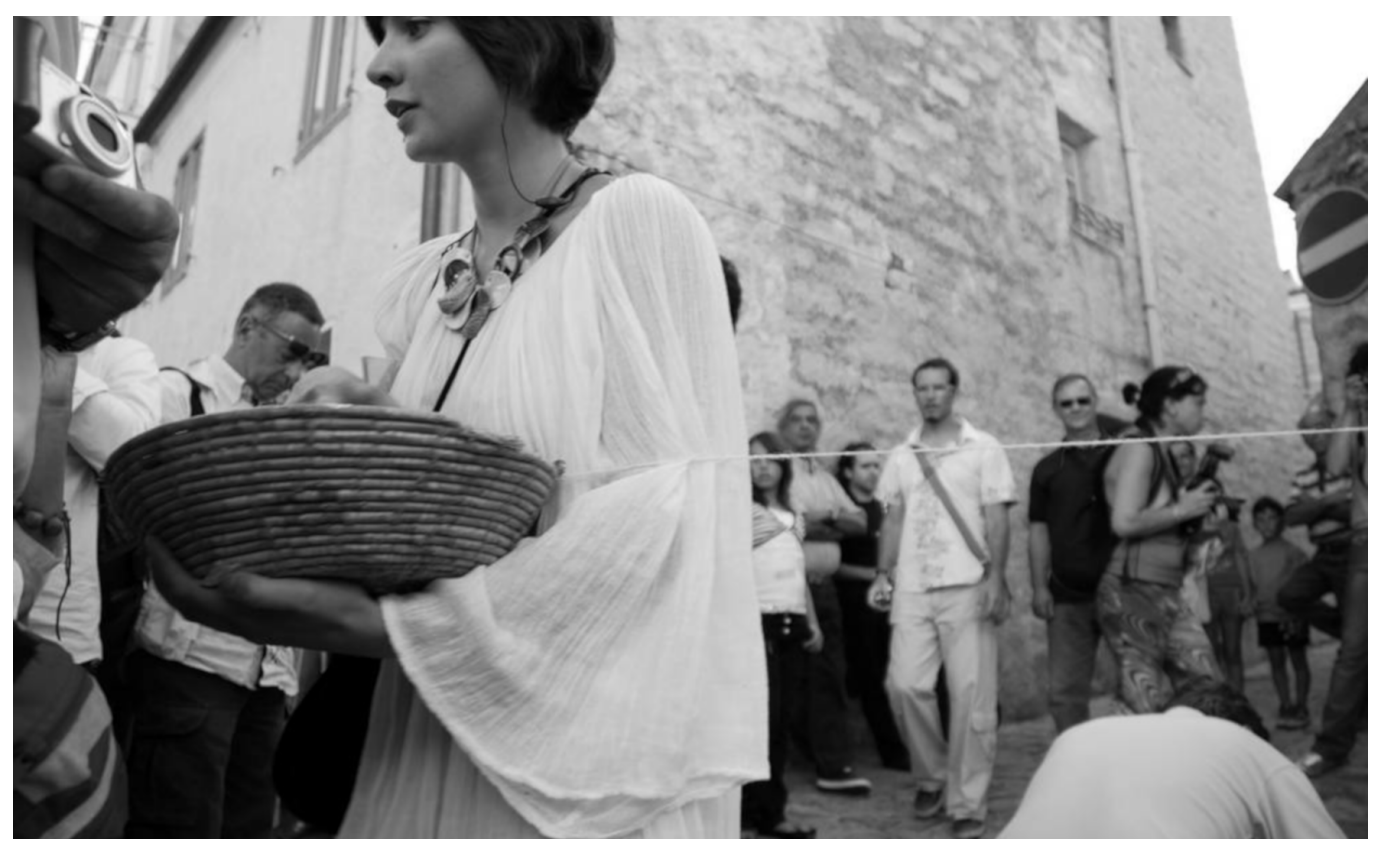


the route, surrounded by Maria Lai's installations spread out in the same environments as scenography. Stylized and painted tapestries, cryptic phrases and letters of the alphabet embroidered with colours, miniature sculpted goats either embroidered or painted on the walls, but especially the fourteen stylized aluminium looms exhibited on panels of different colours -still hanging on the walls of the houses today in memory of the event- radically changed the face of the town (fig. I0).
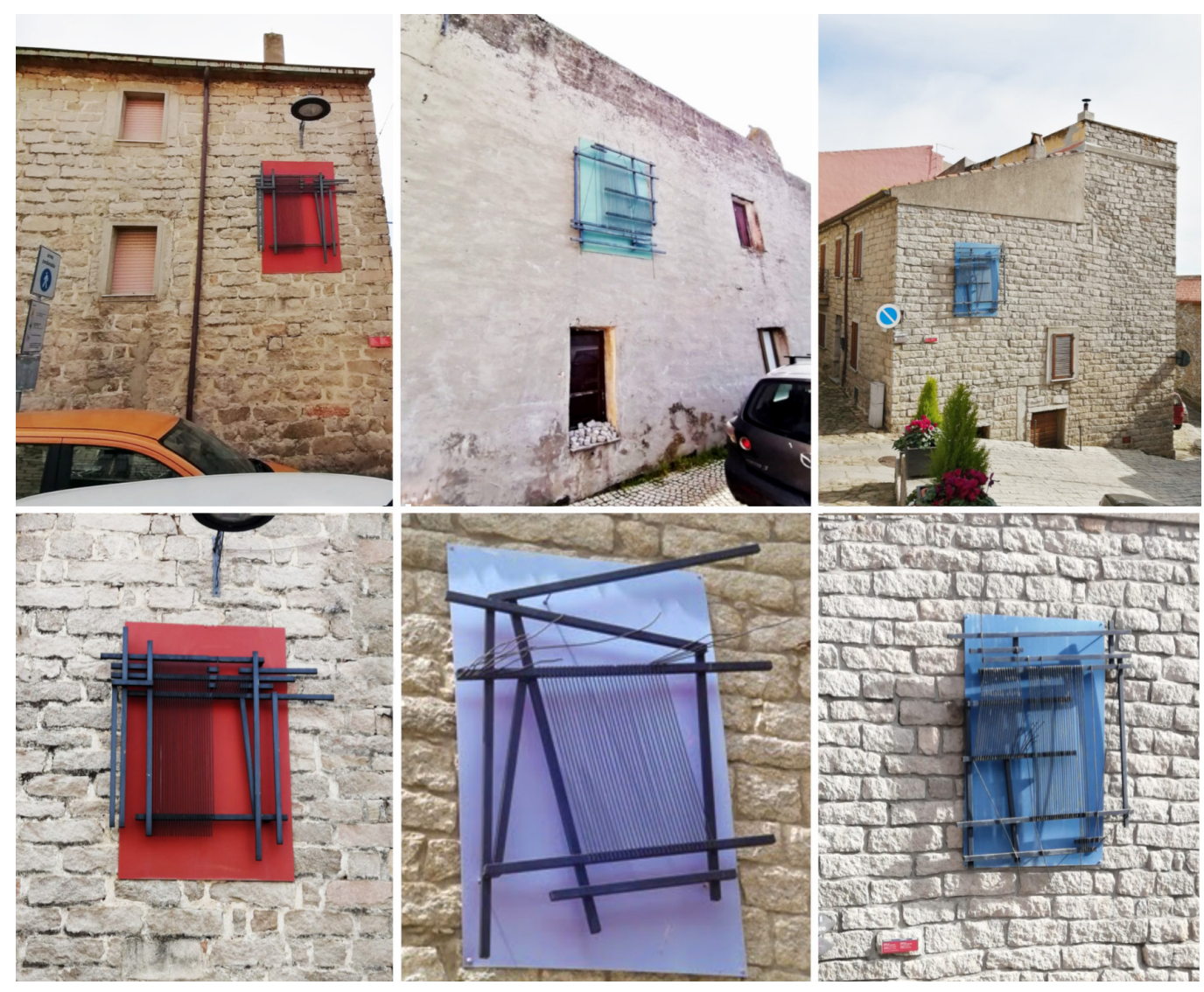

During the performance, the inhabitants interacted among themselves, finding the sense of being a community through the archetype of the loom. A true focus of the initiative was in fact the weaving, whose importance for Aggius is inherent in the title of the work Essere è tessere, a declaration of identity combined with the present. There is no nostalgic memory of the production practices of the past, nor is there an exaltation of the folklore combined with traditional artifice, but rather an affirmation of the present. Lai performs an operation of invisible drawing on the city, tracing paths and leaving footprints that redefine the urban aspect without distorting its usual appearance, in which the local tradition is promoted through a practical and aesthetic experience but above all perceived in the present in such energetic way as to define the very essence of the place (fig. II). The extremely close tie between tradition and territory therefore emerged throughout the operation; a clear clue was the willingness to locate the project directly in the alleys and squares of the town, hosting people, artefacts, and looms, that is, the culture of an entire community [Battista, Saragato 2016]. 
Fig. I I. Interaction of the artist with the local women spinners.
Fig. 12. The mural realized in Cagliari in the sports spaces of the CUS (2016) dedicated to the poetics of Lai: at the two extremes shepherds tending wires, Maria Lai weaving and goats

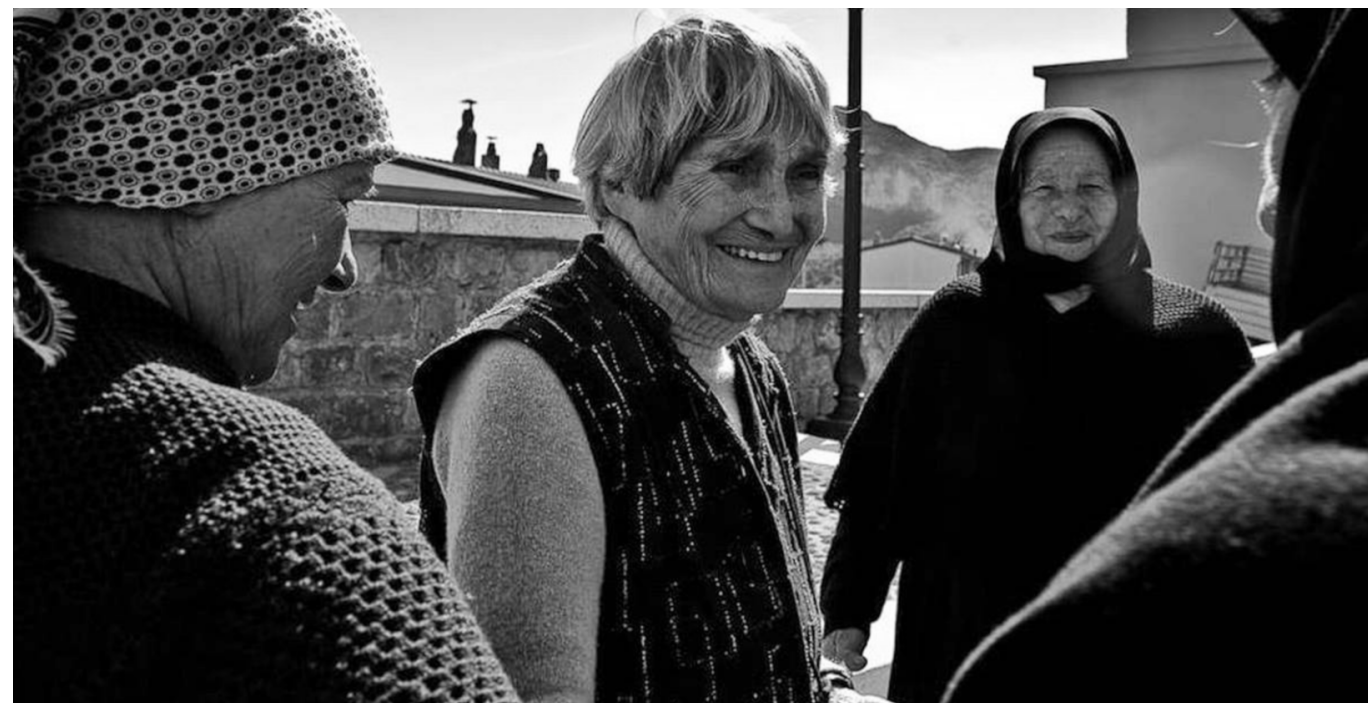

\section{Conclusion}

Lai was not a woman detached from reality. While she was defined as an eternal child who played, but with great seriousness, she was not concealed by fantasy. On the contrary, her artistic sensibility led her to develop profound awareness of the need to cultivate the differences in living together, of knowing how to interpret democracy [Boldrini 20I3].

Her work attests to a rare ability to connect tradition and the present day and an aptitude in knowing how to reconnect the past (ancestral memory) with the present (applications of modernity), transforming it into an opportunity for new knowledge and projection towards a future that combines the particular and universal [Moschini 2018 .

Through a path of exemplary consistency and awareness of the social value of art, Maria Lai was a woman whom today we would define as resilient. She realized many environmental interventions [ $\mathrm{I}]$ to experience and 'read' that, in letting different levels of interpretation exist together, aim to recast a visual and conceptual vocabulary that claims a capacity of meaning for narration. The $35 \mathrm{~m} \times 5 \mathrm{~m}$ murals created in the sports areas of CUS Cagliari (20।6), choral street art [2] with a narrative-visual weave dedicated to Lai's poetry are perhaps testament to how her legacy is felt by the new generations (fig. 12).

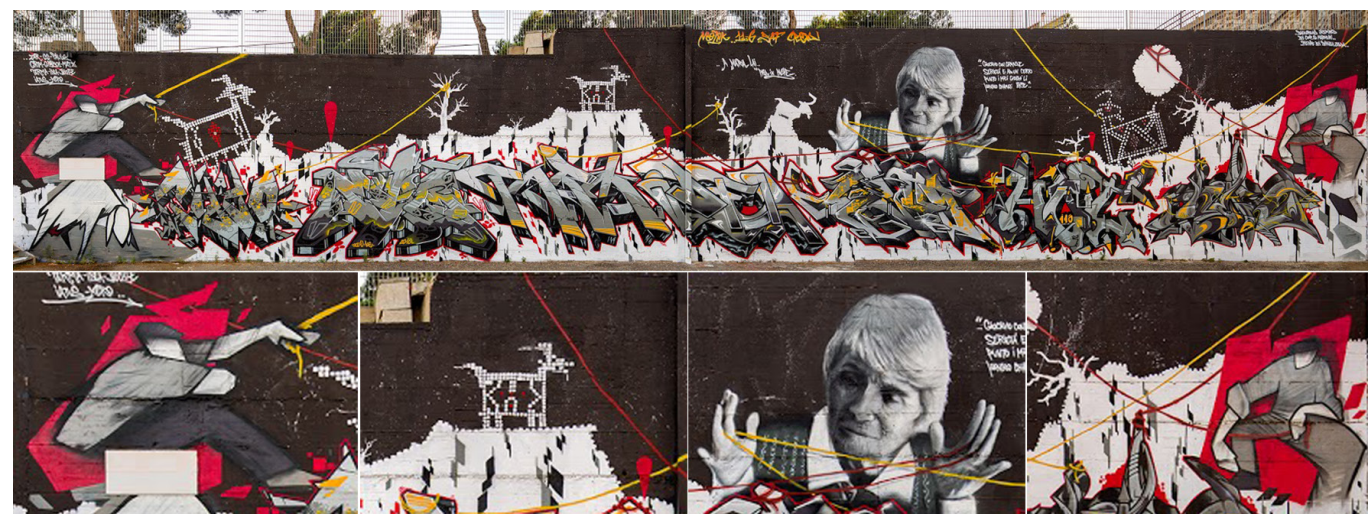

Notes

[I] In Ulissai:Telaio del lavatoio (1982), La strada del rito e Le capre cucite (1992), La scarpata (1993), Paesaggi (1996), Scultura sonara e Cà de Janas (1997), Il gioco del volo dell'oca (2002), La lavagna (2003), II muro del groviglio (2004), La casa delle inquietudini (2005), Libretti murati (2005), Pastorello mattiniero con capretta (2005); works of prelude to the opening of Stazione 
dell'arte (2006). Also in Sardinia: Reperto (1982,Villasimius), L'alveare del poeta (1984, Orotelli), L'albero del miele amaro (I997 Siliqua), La cattura dell'ala del vento (2009, parco eolico di Ulassai), Andando via (2012, Nuoro, monument to Grazia Deledda).

[2] Crew: Sardos Frades Crew, Undici Sei Squad, Neo-Ink. Photo by Francesco e Daniele Brotzu. @[20I 6] by Giuseppe Moro Grim <http://grimdcc.blogspot.it)>

\section{References}

Battista Maria Grazia, Saragato Mario (a cura di). (2016). Un paese che racconta. Aggius: Phileas.

Birrozzi Carlo, Pugliese Marina (2007). L'arte pubblica nello spazio urbano. Committenti, artisti, fruitori. Milano: Bruno Mondadori

Boldrini Laura (Presidente della Camera dei deputati), 2013. Intervento al Convegno "Maria Lai - L'arte tra gioco e magia", Roma, Palazzo Montecitorio, (17.10.13): <https://www.youtube.com/watch?v=cbV4fmcT0Qw>.

Bourriaud Nicolas (20 I0). Arte relazionale. Milano: Postmedia Books. Traduzione di Marco Enrico Giaconelli. (Edizione originale, 1998, Esthétique relationnelle. Dijon: Les presses du réel)

Capulli Maria Grazia ( 1984). L'artista del varano. In L'Appennino Camerte, n. 44, pp. 2.

Cuccu Giuseppina, Lai Maria (2002). Le ragioni dell'arte. Cose tanto semplici che nessuno capisce. Cagliari: Arte Duchamp.

Guerra Medici Maria Teresa (2002). Famiglia e potere in una signoria dell'Italia centrale: i Varano di Camerino. Camerino: Università degli Studi.

Ladogana Rita (20|4). «Fiabe intrecciate». La scultura di Maria Lai dedicata ad Antonio Gramsci. In Terra Gramsci (a cura di) Maremuro. Appunti per un dialogo realmeraviglioso. Maria Lai in dialogo con Antonio Gramsci. Cagliari: CUEC, pp. 25-29.

Lai Maria (1988). Da una conversazione tra Maria Lai e Mario De Candia, Roma, 20 novembre 1986. In Ciusa Maria Elvira, Bua Mimmo, De Candia Mario, Zaru Francesca A. A matita: disegni di Maria Lai dal 194 I al 1985. Milano: Franco Maria Ricci per Arte Duchamp.

Lai Maria (1984-2004). Tenendo per mano il sole. <https://www.youtube.com/watch?v=G3_wA3Wg5js>; <https://www.maxxi. art/events/maria-lai-tenendo-per-mano-il-sole/>.

Lai Maria (2005). L'isola delle storie: <https://www.youtube.com/watch?v=T4EPJRQDe9M>

Lai Maria (20I I). Inventata da un Dio distratto - parte I. <https://www.youtube.com/watch?v=TL8mGWVreel>

Moschini Francesco (2018). Intervento alla "Presentazione volume Maria Lai. Arte e relazione di Elena Pontigia", Roma, Accademia di San Luca, (27.03.20 I): <https://www.youtube.com/watch?v=R600fQeBzql>

Paino Fiorella (200 I). D'azzurro o di verde? Note sull'insegna araldica dei da Varano di Camerino. In De Marchi Andrea, Falaschi Pierluigi (a cura di). I da Varano e le arti. Atti Del Convegno internazionale Camerino. Palazzo Ducale 4-6 Ottobre 200 I, vol. I, pp. 109-124. Ripatransone: Maroni.

Pioselli Alessandra (20 I5). L'arte nello spazio urbano. L'esperienza italiana dal 1968 a oggi. Monza: Johan\&Levi.

Pontiggia Elena (20 17). Maria Lai. Arte e relazione. Nuoro: llisso.

Santarelli Vera (1984). II varano alle finestre? Era solo una provocazione. In L'Appennino Camerte, n. I9, pp. 2.

\section{Authors}

Alessandra Meschini, Università di Camerino, alessandra.meschini@unicam.it

Alessandro Basso, Libera Università di Bolzano, alessandro.basso@unibz.it

To cite this chapter. Meschini Alessandra, Basso Alessandro (2020). Narrazioni visuali attraverso il tempo e lo spazio: trame e metafore di connessioni per lo spazio pubblico/Visual narratives through time and space: weaves and metaphors of connections for public space. In Arena A., Arena M., Brandolino R.G., Colistra D., Ginex G., Mediati D., Nucifora S., Raffa P. (a cura di). Connettere. Un disegno per annodare e tessere. Atti del $42^{\circ}$ Convegno Internazionale dei Docenti delle Discipline della Rappresentazione/Connecting. Drawing for weaving relationships. Proceedings of the 42th International Conference of Representation Disciplines Teachers. Milano: FrancoAngeli, pp. 3533-3552. 